\title{
HUBUNGAN KEMAMPUAN BERPIKIR KREATIF DAN KRITIS DENGAN PRESTASI BELAJAR MAHASISWA PADA MATAKULIAH KONSEP SAINS II PRODI PGSD IKIP PGRI MADIUN
}

\author{
Imam Gunawan * \\ Selly Nurina Suraya* \\ Dewi Tryanasari *
}

\begin{abstract}
Critical thinking in education has been widely practiced following the awareness that it helps a lot the students specifically in science subjects. In accordance with critical thinking ability in science, students who show ability on critical thinking will successfully cope with problems they encounter. Such ability hopefully works in their learning achievement. The objective of this research is to investigate the influence of creative and critical thinking on the achievement of the students of the Department of Primary Education IKIP PGRI Madiun in the class of Science Concepts II. The current study makes use of the descriptive correlational. As many as 191students enrolled the class of science concepts II in the academic year 2012/2013, out of 366 populations, serve as the sample through the proportional random sampling technique. Tests were administered to collect the data analyzed by applying descriptive analysis of double regression to assess the hypothesis in which SPSS PASW Statistics 18 was applied. Results show that there is significant correlation on the variables of creative and critical thinking on their achievement. The creative thinking contributes $20.13 \%$ while the critical thinking contribution is $21.53 \%$. Other variables beyond this research contribute $58.34 \%$.
\end{abstract}

Key words: Creative Thinking Ability, Critical Thinking, Student Achievement

\begin{abstract}
Abstrak
Pengembangan kemampuan berpikir kritis dalam pendidikan banyak dilakukan setelah disadari bahwa kemampuan berpikir kritis sangat bermanfaat bagi peserta didik terutama dimulai pada pelajaran sains. Sesuai dengan kemampuan berpikir ilmiah dalam sains, peserta didik yang memiliki kemampuan berpikir kritis akan memiliki kemampuan untuk memecahkan setiap permasalahan yang dihadapi dengan baik. Kemampaun tersebut diharapkan dapat menopang prestasi belajar mahasiswa. Tujuan penelitian ini adalah untuk mengetahui pengaruh kemampuan berpikir kreatif dan kritis terhadap prestasi belajar mahasiswa PGSD FIP IKIP PGRI MADIUN dalam matakuliah
\end{abstract}

\footnotetext{
* Imam Gunawan adalah Dosen Prodi PGSD FIP IKIP PGRI MADIUN

* Selly Nurina Suraya adalah Dosen Prodi PGSD FIP IKIP PGRI MADIUN

* Dewi Tryanasari adalah Dosen Prodi PGSD FIP IKIP PGRI MADIUN
} 
Konsep Sains II. Penelitian ini menggunakan model penelitian deskriptif korelasional. Jumlah sampel penelitian adalah 191 orang mahasiswa dari total populasi 366 orang mahasiswa peserta matakuliah Konsep Sains II PGSD FIP IKIP PGRI MADIUN Tahun Akademik 2012/2013. Teknik proporsional random sampling untuk menentukan besarnya sampel di setiap program studi. Teknik pengumpulan data dalam penelitian ini adalah dengan menggunakan teknik tes. Teknik analisis data yang digunakan adalah analisis deskriptif dan analisis regresi ganda untuk uji hipotesis dengan bantuan program SPSS PASW Statistics 18. Hasil penelitian menunjukkan bahwa terdapat hubungan yang signifikan pada variabel kemampuan berpikir kreatif dan kritis terhadap prestasi belajar mahasiswa Matakuliah Konsep Sains II Program Studi PGSD IKIP PGRI MADIUN. Besarnya sumbangan efektif variabel kemampuan berpikir kreatif adalah $20,13 \%$ dan sumbangan efektif variabel kemampuan berpikir kritis adalah $21,53 \%$ terhadap prestasi belajar dan variabel lain yang memengaruhi prestasi belajar di luar penelitian sebesar 58,34\%.

Kata kunci: Kemampuan Berpikir Kreatif, Kritis, Prestasi Belajar Mahasiswa.

\section{A. Pendahuluan}

Jaman terus berkembang dari waktu ke waktu. Perkembangan ini dipengaruhi oleh perkembangan sains dan teknologi, di mana hanya generasigenerasi yang memiliki kemampuan dan prestasi lebih yang akan dapat meraih keberhasilan dan kesuksesan. Kemampuan dan prestasi ini tidak begitu saja dimiliki oleh generasi muda begitu saja, namun dipelajari melalui proses pendidikan. Menjawab tantangan jaman, dunia pendidikan juga mulai mengalami perubahan ke arah yang lebih baik. Berbagai teknik membelajarkan mahasiswa banyak bermunculan. Kampus yang pada awalnya terfokus pada kegiatan menuntut ilmu, sekarang mulai diperbaharui dengan meningkatkan pembelajaran pada aspek-aspek kemampuan yang lain.

Salah satu kemampuan lain yang dituntut untuk dikembangkan adalah kemampuan berpikir kritis. Pengembangan kemampuan berpikir kritis dalam pendidikan banyak dilakukan setelah disadari bahwa kemampuan berpikir kritis sangat bermanfaat bagi peserta didik terutama dimulai pada pelajaran sains. Sesuai dengan kemampuan berpikir ilmiah dalam sains, peserta didik yang memiliki kemampuan berpikir kritis akan memiliki kemampuan untuk memecahkan setiap permasalahan yang dihadapi dengan baik. Sejalan dengan latar belakang di atas, Wardani (2008) menyatakan bahwa kegiatan pembelajaran hendaknya mempersiapkan peserta didik yang memiliki kemampuan dalam menyelesaikan permasalahan, kritis, dan kreatif, dalam kondisi yang berwawasan nasional, regional, dan global. Matakuliah sains yang mengarah pada kemampuan berpikir ilmiah mengajarkan kepada mahasiswa untuk selalu siap menerima setiap permasalahan yang dihadapi dengan tenang, memecahkan permasalahan tersebut dengan baik, dan memanfaatkan hasil pemecahan masalah tersebut dalam kehidupan individu atau bagi kepentingan orang banyak. 
Matakuliah sains memerlukan kemampuan berpikir kreatif dan kritis dalam kegiatan pembelajarannya. Menumbuhkan kemampuan berpikir kreatif, kritis, bekerja, dan bersikap ilmiah serta berkomunikasi sebagai salah satu aspek penting kecakapan hidup dalam kegiatan pembelajaran sains dapat dilaksanakan secara inkuiri ilmiah. Mahasiswa yang memiliki kemampuan untuk berpikir kreatif dan kritis akan dapat menilai perkembangan Ilmu Pengetahuan Alam (IPA) dalam teknologi dan dampaknya dalam kehidupan (Puskur, 2007). Berdasarkan hasil studi pendahuluan yang dilakukan peneliti di program studi PGSD FIP IKIP PGRI MADIUN, kegiatan pembelajaran sains mahasiswa kurang mengarahkan mahasiswa kepada aspek-aspek penting kecakapan hidup melalui pembelajaran inkuiri ilmiah. Berdasarkan hasil wawancara dengan sejumlah mahasiswa PGSD semester 1, 3, dan 5 tahun akademik 2012/2013 disimpulkan bahwa dalam kelas sains, mahasiswa masih pasif dan hanya mendengarkan atau mencatat penjelasan dosen, mengerjakan soal-soal yang diberikan, kemudian membawa tugas untuk dikerjakan dan dibahas atau dikumpulkan pada pertemuan selanjutnya. Berdasarkan hasil observasi menunjukkan bahwa matakuliah sains yang diberikan sebatas penurunan rumus-rumus sains yang kemudian digunakan untuk mengerjakan soal-soal yang diberikan oleh dosen.

Saat kegiatan pembelajaran berlangsung dan dosen menanyakan apakah ada materi yang tidak dimengerti, mahasiswa cenderung diam dan tidak mengajukan pertanyaan, namun ketika ujian berlangsung mahasiswa merasa kesulitan dalam mengerjakan soal-soal yang diberikan oleh dosen. Metode pembelajaran yang diterapkan oleh dosen juga masih terbatas pada metode ceramah atau teaching by telling dan ekspositori. Kegiatan pembelajaran tersebut membuat mahasiswa terbiasa mengerjakan berbagai tipe soal-soal sains, namun ketika diberikan permasalahan yang mengarah pada kehidupan sehari-hari, mahasiswa mengalami kesulitan untuk mengaplikasikan teori-teori yang diperoleh dan mengintegrasikan dengan peristiwaperistiwa dalam kehidupan sehari-hari. Kemampuan mahasiswa untuk mengintegrasikan teori-teori yang dipelajari di kampus dengan peristiwa dalam kehidupan sehari-hari sangat memerlukan keahlian berpikir kreatif dan kritis.

Kegiatan pembelajaran yang kurang mengembangkan kemampuan mahasiswa untuk berpikir kreatif dan kritis seperti di atas menunjukkan bahwa pembelajaran sains di Program Studi Pendidikan Guru Sekolah Dasar (Prodi PGSD) FIP IKIP PGRI MADIUN belum dapat memenuhi tujuan pendidikan yang diharapkan. Belum terpenuhinya kegiatan pembelajaran yang mengarah pada pengoptimalan kemampuan berpikir kreatif dan kritis mahasiswa dikhawatirkan dapat menyebabkan prestasi belajar sains mahasiswa menurun, selain itu mahasiswa mengalami kesulitan menyesuaikan diri dengan perkembangan jaman. Kekhawatiran ini masih bersifat pernyataan berdasarkan studi lapangan dan teoritik pendahuluan yang masih perlu dibuktikan secara ilmiah, untuk itu perlu diadakan penelitian tentang hubungan kemampuan berpikir kreatif dan kritis terhadap prestasi belajar sains.

Penelitian ini didukung oleh penelitian terdahulu antara lain: penelitian yang dilakukan oleh Ernawati (2000) yang meneliti tentang hubungan antara kemampuan berpikir kreatif dan sikap kreatif dengan prestasi belajar; Siregar (2006) yang meneliti tentang kontribusi sikap terhadap berpikir kreatif dan aktivitas mahasiswa terhadap prestasi belajar; Ragasa (2007) yang meneliti tentang korelasi kemampuan berpikir kritis dengan prestasi belajar statistik; dan Wu (1992) yang meneliti tentang 
hubungan antara kemampuan berpikir kritis dengan prestasi belajar mahasiswa sekolah dasar dan sekolah menengah. Berdasarkan latar belakang di atas, untuk mengetahui seberapa tinggi kemampuan berpikir kreatif dan kritis mahasiswa dan apakah kemampuan berpikir kreatif dan kritis mahasiswa ada hubungannya dengan prestasi belajar sains mahasiswa, maka diadakan penelitian tentang hubungan kemampuan berpikir kreatif dan kritis dengan prestasi belajar mahasiswa pada Matakuliah Konsep Sains II Program Studi PGSD IKIP PGRI MADIUN.

Salim (2002:776) menyatakan bahwa kemampuan berpikir kreatif adalah kemampuan mencipta, sedangkan kreativitas menurut Campbell adalah suatu ide atau pemikiran manusia yang bersifat inovatif, berdaya guna (useful), dan dapat dimengerti (understandable) (ADVY: 2007). Seorang mahasiswa harus banyak bertanya, banyak belajar, dan berdedikasi tinggi untuk memperoleh kemampuan berpikir kreatif yang tinggi. Menurut Andangsari (2007) kemampuan berpikir kreatif dapat diartikan sebagai kemampuan menempatkan sejumlah objek-objek yang ada dan mengombinasikannya menjadi bentuk yang berbeda untuk tujuantujuan yang baru. Melakukan pencarian berbagai macam informasi yang dapat mendukung kemudahan dalam memahami ilmu pengetahuan akan dapat meningkatkan kemampuan berpikir kreatif. Munandar (2002:25-29) mendefinisikan pengertian kreativitas dengan menggunakan pendekatan empat $\mathrm{P}$, antara lain pendekatan pribadi, proses, produk, dan pendorong. Beberapa definisi dari kreativitas berdasarkan pendekatan empat $P$ yaitu:

1. Definisi Pribadi yang menyatakan bahwa kreativitas merupakan perilaku seseorang yang memiliki kepribadian mengagumkan dalam menghadapi dan hidup bermasyarakat dengan cara yang unik. Seseorang yang memiliki kemampuan berpikir kreatif akan dapat memiliki karakteristik atau ciri khas yang berbeda walaupun berada dalam lingkungan yang sama dengan orang lain;

2. Definisi Proses, menjelaskan tentang proses yang dilakukan oleh seseorang dengan kemampuan berpikir kreatif antara lain mengerti adanya permasalahan, kesulitan, perbedaan informasi terhadap suatu hal, bagianbagian yang hilang dalam informasi, atau beberapa hal yang menjadi pertanyaan sehingga mampu membuat praduga atau hipotesis berkaitan dengan kekurangan yang baru ditemukan. Praduga yang telah dibuat selanjutnya dievaluasi dan hasil yang telah diperoleh dikomunikasikan;

3. Definisi Produk, di mana produk yang dihasilkan oleh orang yang memiliki kemampuan berpikir kreatif akan menghasilkan produk yang lebih menekankan pada unsur-unsur orisinalitas, kebaruan, dan kebermaknaan. Rogers mengemukakan kriteria produk yang harus dihasilkan oleh orangorang yang dapat berpikir kreatif antara lain nyata (observable), baru, dan merupakan hasil dari kualitas unik individu dalam interaksi dengan lingkungannya (Munandar, 2002:28);

4. Definisi Pendorong, yang menyatakan bahwa kemampuan berpikir kreatif pada seseorang akan dapat muncul dengan baik jika orang tersebut memiliki motivasi intrinsik yang baik dan berada pada lingkungan yang mendorong kreativitas orang tersebut secara positif.

Berdasarkan beberapa pengertian di atas dapat ditarik kesimpulan bahwa kemampuan berpikir kreatif dapat diartikan sebagai kemampuan menciptakan 
sesuatu yang baru, atau kemampuan menempatkan dan mengombinasikan sejumlah objek secara berbeda yang berasal dari pemikiran manusia yang bersifat dapat dimengerti, berdaya guna, dan inovatif dengan berbagai macam faktorfaktor yang dapat mempengaruhi. Kreativitas lebih mengutamakan segi penemuan atau hal baru melalui proses tertentu. Adanya sikap inovasi mahasiswa dalam melaksanakan kegiatan pembelajaran merupakan proses menuju kreativitas. Kemampuan berpikir kreatif memiliki ciri-ciri perilaku yang meliputi 4 subvariabel yaitu kelancaran (fluency), kerincian (elaboration), fleksibilitas (Flexibility) dan orisinalitas (originality). Munandar (1990:88-90) mencirikan masing-masing perilaku ini, yakni sebagai berikut.

Kelancaran merupakan kemampuan mencetuskan banyak gagasan, jawaban, penyelesaian suatu masalah, atau pertanyaan yang diajukan dengan mudah. Anak yang lancar berpikir kreatif akan memiliki banyak cara atau saran untuk melakukan berbagai hal. Selain itu, jika seorang anak yang lancar berpikir kreatif diberi suatu pertanyaan dia akan cenderung memberikan beberapa alternatif jawaban. Ciri-ciri anak yang lancar berpikir kreatif adalah banyak bertanya, memiliki banyak alternatif jawaban, memiliki banyak gagasan/ide dalam menyikapi sesuatu, dalam berinteraksi anak akan bekerja lebih banyak dan melakukan lebih banyak hal dibandingkan dengan teman-temannya. Anak yang lancar berpikir kreatif juga cenderung dapat mengidentifikasi kesalahan atau kekurangan pada suatu obyek dengan cepat.

Kerincian merupakan kemampuan memperkaya atau mengembangkan suatu gagasan yang dimiliki oleh diri sendiri maupun orang lain. Anak yang dapat berpikir kreatif secara rinci akan mampu menambahkan detail-detail tertentu dari suatu obyek, gagasan, dan situasi sehingga lebih menarik. Ciri-ciri anak yang dapat berpikir kreatif secara rinci adalah selalu mencari arti yang lebih dalam terhadap jawaban pertanyaan yang diajukan, melakukan pemecahan masalah dengan cara yang terperinci, mampu mengembangkan atau memperkaya gagasan orang lain, selalu mau mencoba atau menguji detail-detail suatu obyek untuk melihat arah-arah yang akan ditempuh, dan memiliki rasa keindahan yang kuat sehingga tidak puas dengan penampilan kosong atau sederhana.

Fleksibel dalam berpikir kreatif merupakan kemampuan menghasilkan banyak alternatif gagasan, pertanyaan dan jawaban yang bervariasi, kemampuan melihat sesuatu dari sudut pandang yang berbeda, kemampuan mencari banyak alternatif/arah yang berbeda. Fleksibel dalam berpikir kreatif memungkinkan seseorang mampu mengubah pendekatan atau cara pemikiran dengan mudah. Ciriciri anak yang berpikir kreatif secara fleksibel adalah mampu menunjukkan aneka ragam penggunaan yang tidak lazim dari suatu obyek, mampu memberi berbagai macam penafsiran (interpretasi) terhadap sesuatu gambar, cerita, dan masalah, mampu menerapkan suatu konsep atau asas dengan cara yang berbeda-beda. Anak yang fleksibel dalam berpikir kreatif juga akan cenderung memiliki posisi yang berbeda atau bahkan bertentangan dengan mayoritas kelompoknya ketika melakukan diskusi atau membahas suatu masalah bersama-sama. Anak yang fleksibel dalam berpikir kreatif cenderung menggolongkan hal-hal menurut pembagian atau kategori yang berbeda dan mampu mengubah arah pemikiran secara spontan.

Orisinal dalam berpikir kreatif merupakan kemampuan melahirkan ungkapan baru yang unik, kemampuan memikirkan cara yang tidak lazim untuk 
mengungkapkan diri sendiri, dan kemampuan membuat kombinasi-kombinasi yang tidak lazim dari bagian-bagian atau unsur-unsur. Ciri-ciri anak yang berpikir kreatif secara orisinal adalah selalu memikirkan masalah-masalah atau hal-hal yang tidak pernah terpikirkan oleh orang lain, selalu mempertentangkan cara-cara yang lama dan berusaha memikirkan cara-cara yang baru. Anak yang orisinal dalam berpikir kreatif cenderung memilih sesuatu yang asimetri dalam membuat gambar dan desain suatu obyek, selalu mencari pendekatan yang baru dari yang stereotip, dan lebih menyenangi sesuatu yang bersifat sintesis daripada sekedar menganalisis. Anak yang orisinalitas dalam berpikir kreatif akan bekerja untuk menemukan permasalahan yang baru setelah membaca atau mendengar gagasan.

Pada dasarnya semua mahasiswa memiliki kreativitas, namun hanya beberapa mahasiswa saja yang dapat memanfaatkan kemampuan berpikir kreatif yang dimiliki, dengan kata lain, mahasiswa memerlukan pembimbingan untuk mengembangkan berpikir kreatif. Kemampuan mahasiswa mempergunakan pikiran kreatif mereka akan tampak dari perilaku mahasiswa dalam kegiatan pembelajaran maupun pada perilaku mahasiswa sehari-hari. Rogers menekankan bahwa sumber seseorang dapat berpikir kreatif adalah kecenderungan seseorang mengaktualisasikan diri, mewujudkan potensi dan dorongan untuk berkembang dan menjadi matang, kecenderungan mengekspresikan dan mengaktifkan semua kemampuan organisme (Munandar, 2002:24). Sekolah sebagai lembaga pendidikan formal merupakan tempat memfasilitasi mahasiswa agar dapat lebih mengaktualisasikan diri, mengembangkan potensi untuk menjadi matang dan mampu mengekspresikan diri menjadi manusia yang mampu berpikir kreatif dengan baik yang memiliki kemampuan dan kemungkinan untuk menghadapi tuntutan dan perkembangan zaman. Einstein mengemukakan bahwa:

Sebetulnya setiap manusia memiliki kemampuan berpikir kreatif. Dengan demikian tidak ada alasan seseorang mengatakan "Saya bukan orang yang kreatif", yang ada hanyalah belum mengasah potensi kemampuan berpikir kreatif yang dimilikinya. Semakin sering seseorang mengikuti pelatihan yang mengasah kemampuan berpikir kreatif, maka semakin baik potensi kemampuan berpikir kreatif yang dimiliki (Andangsari, 2007).

Andangsari (2007) berpendapat bahwa kemampuan berpikir kreatif biasa terjadi karena seseorang mencoba sesuatu dengan sengaja. Berawal kesengajaan seseorang mampu mengerjakan tugas-tugasnya dan akhirnya terbiasa. Kemampuan berpikir kreatif dapat muncul karena seseorang terbiasa berkreasi. Mahasiswa dapat melakukan berbagai macam percobaan sederhana setelah menerima pelajaran atau teori tertentu dalam kegiatan pembelajaran sains, sehingga mahasiswa akan dapat lebih memahami konsep-konsep yang terdapat dalam matakuliah sains. Kegiatan pembelajaran sains sangat memerlukan kreativitas, baik dari pihak dosen maupun mahasiswa. Kemampuan menyesuaikan diri dengan perubahan dan kemampuan melakukan penemuan bukanlah hal yang sulit dengan memiliki sifat kreatif. Mahasiswa dituntut berpikir kreatif dalam mempelajari sains sehingga dapat memahami pelajaran yang diterima dengan lebih baik. Bachman (2005:7) menyatakan bahwa berpikir kreatif dalam usaha pencarian inovasi merupakan cara yang paling baik untuk memahami konsepkonsep dan model penggunaan pengetahuan yang paling efektif dan efisien. 
Kemampuan berpikir kreatif yang dimiliki mahasiswa dapat memudahkan mahasiswa dalam memperdalam ilmu pengetahuan yang dimiliki dan mempertajam kemampuan mahasiswa untuk menganalisis permasalahanpermasalahan yang timbul dalam usahanya mempelajari materi tertentu, sehingga mahasiswa dapat mempelajari materi-materi yang disajikan di lingkungan sekolah dengan baik, dan mampu menerapkan ilmu pengetahuan yang telah didapatkannya di lingkungan sekitar. Kemampuan berpikir kreatif dapat diketahui oleh orang lain di sekitar. Seorang dosen hendaknya mengetahui kemampuan berpikir kreatif dari mahasiswa-mahasiswanya sehingga dapat mengenali karakteristik mahasiswanya dan pada akhirnya dapat menerapkan metode pembelajaran yang sesuai dengan karakteristik mahasiswa.

Berbagai macam metode untuk menguji kemampuan berpikir kreatif telah banyak ditemukan oleh para ahli, yakni: alat tes yang mengukur kemampuan berpikir kreatif dari Guilford, tes Torrance dan tes berpikir kreatif produktif. Alat tes yang mengukur kemampuan berpikir kreatif dari Guilford mengukur kemampuan berpikir divergen sebagai operasi mental yang menuntut penggunaan kemampuan berpikir. Tes yang diajukan oleh Guilford menekankan pada berbagai jawaban yang diutarakan oleh sampel penelitian berkaitan dengan satu permasalahan yang diajukan kepada sampel. Jawaban yang diutarakan oleh sampel penelitian dinilai dengan persyaratan kelancaran, kerincian, fleksibilitas, dan orisinalitas.

Kritis berkaitan dengan memiliki ketajaman dalam menganalisis suatu hal atau persoalan dan pengambilan keputusan. Semakin tajam seseorang menganalisis suatu permasalahan maka akan semakin tajam pula keputusan yang dibuat oleh orang tersebut. Ennis menjelaskan bahwa berpikir kritis adalah berpikir secara beralasan dan reflektif dengan menekankan pada pembuatan keputusan tentang apa yang harus dipercayai atau dilakukan (Hassoubah, 2007:87). Johnson dan Lamb (2000) mengemukakan bahwa: critical thinking involves logical thinking and reasoning including skills such as comparison, classification, sequencing, causeleffect, patterning, webbing, analogies, deductive, and inductive reasoning, forecasting, planning, hypothesizing, and critiquing.

Berpikir kritis meliputi berpikir logis dan beralasan berkaitan dengan keterampilan seperti membandingkan, menggolongkan, mengurutkan, sebab akibat, menyusun, mengaitkan, analogi, proses berpikir deduktif, dan penyebab induktif, ramalan, rencana, membuat hipotesis, dan tinjauan kritis. Pengertian lain diungkapkan oleh Setiono (2007) yang menjelaskan bahwa berpikir kritis adalah suatu aktivitas kognitif yang berkaitan dengan penggunaan nalar. Belajar berpikir kritis berarti menggunakan proses-proses mental, seperti memperhatikan, mengategorikan, seleksi, dan menilai / memutuskan, sedangkan Nurcahyo (2005) menyatakan bahwa berpikir kritis adalah proses mental untuk menganalisis atau mengevaluasi informasi. Informasi tersebut dapat didapatkan dari hasil pengamatan, pengalaman, akal sehat atau komunikasi.

Berdasarkan pengertian-pengertian di atas dapat disimpulkan bahwa berpikir kritis merupakan proses mental yang melibatkan aktivitas kognitif secara beralasan dan reflektif, yang bertujuan untuk memecahkan masalah dan menemukan penyelesaian, kemudian menghasilkan suatu keputusan dan melibatkan keterampilan-keterampilan berpikir logis dan analitis. Ennis dan Marzano (1989: 69-113) mengemukakan bahwa kemampuan berpikir kritis terdiri 
atas 5 subvariabel, yakni: (1) memfokuskan; (2) memeroleh informasi; (3) mengingat; (4) menganalisis; dan (5) mengevaluasi.

Kemampuan memfokuskan masalah yang dilakukan memungkinkan seseorang memunculkan bagian-bagian informasi yang diperlukan dan mengabaikan informasi-informasi lain yang tidak diperlukan. Memfokuskan masalah dapat dilakukan dengan menentukan permasalahan yang diajukan dan menentukan tujuan permasalahan. Kemampuan memperoleh informasi merupakan kemampuan dalam meringkas pengetahuan-pengetahuan untuk dimanfaatkan dalam proses kognitif. Memperoleh informasi terdiri dari kemampuan mengamati dan merumuskan pertanyaan. Kemampuan mengingat merupakan kemampuan yang dimiliki seseorang untuk menyimpan informasi dalam waktu yang cukup lama dan memanggil kembali informasi tersebut ketika dibutuhkan. Mengingat terdiri atas kemampuan menyimpan informasi (encoding) dan menggunakannya (recalling). Kemampuan menganalisis digunakan untuk mengklarifikasikan informasi dengan menguji tiap-tiap bagian pengetahuan atau informasi. Menganalisis terdiri atas kemampuan mengidentifikasi atribut dan komponen, hubungan dan pola, ide pokok, serta terjadinya kesalahan. Kemampuan mengevaluasi merupakan kemampuan seseorang dalam menilai pertanggungjawaban dan kualitas ide yang diajukan. Mengevaluasi terdiri atas kemampuan menentukan kriteria dan memverifikasi hasil penelitian.

Jika kemampuan berpikir kreatif bersifat divergen, maka kemampuan berpikir kritis lebih bersifat konvergen. Kemampuan ini menghasilkan mahasiswa yang memiliki kemampuan menemukan jawaban yang tepat dari suatu masalah yang dipertanyakan kepada mahasiswa. Kemampuan berpikir kritis dari seorang mahasiswa dapat diketahui dengan memberikan pertanyaan kepada mahasiswa dan meminta mahasiswa menjawab pertanyaan tersebut. Pertanyaan yang diajukan adalah pertanyaan yang memungkinkan mahasiswa menstimulasikan pengetahuan-pengetahuan yang oleh dimiliki untuk membangun pengetahuan baru. Setiono (2007) menyatakan bahwa mengembangkan kemampuan berpikir kritis merupakan kegiatan mengintegrasi pengembangan beberapa kemampuan seperti pengamatan (observasi), analisis, penalaran, penilaian, pengambilan keputusan, dan persuasi. Mengembangkan kemampuan-kemampuan ini akan menghasilkan kemampuan mengatasi masalah-masalah dengan hasil yang memuaskan. Berpikir kritis merupakan kemampuan yang perlu diasah terus menerus. Semakin sering melatih mahasiswa berpikir kritis maka akan semakin tajam pula kemampuan berpikir kritis mahasiswa.

Kegiatan pembelajaran yang dapat mengembangkan kemampuan berpikir kritis mahasiswa dengan baik merupakan kegiatan yang mengasah kemampuan mahasiswa berpikir tingkat tinggi. Hal ini dapat dilakukan dengan membiasakan mahasiswa menghadapi masalah dengan memberikan pertanyaan dan permasalahan yang mengarahkan mahasiswa untuk berpikir kritis. Pada awalnya mungkin mahasiswa akan ketakutan dan tidak memiliki keberanian menyampaikan jawabannya. Hal ini cukup wajar karena sebagian besar kegiatan pembelajaran di kampus belum mengarah pada pembelajaran berpikir kritis. Mengatasi hal ini dosen hendaknya bersabar dan tetap membimbing mahasiswa dengan tekun. Lama kelamaan mahasiswa akan terbiasa dengan pertanyaanpertanyaan dan permasalahan, sehingga semakin lama akan semakin tertantang memecahkan permasalahan yang semakin sulit. 
Resnick dan Gokhale menyarankan bahwa pembelajaran yang dilakukan dengan model diskusi kelompok kecil juga dapat dilakukan untuk mengembangkan kemampuan berpikir kritis (Sudaryanto, 2007). Mahasiswa yang tergabung dalam kelompok kecil akan mendapat kesempatan mengklarifikasi pemahamannya dan mengevaluasi pemahaman mahasiswa lain, mengobservasi strategi berpikir dari orang lain untuk dijadikan panutan, membantu mahasiswa lain yang kurang untuk membangun pemahaman, meningkatkan motivasi, serta membentuk sikap yang diperlukan seperti menerima kritik dan menyampaikan kritik dengan cara yang santun. Berbagai macam alat mengukur kemampuan berpikir kritis telah dikembangkan oleh para ahli. Ennis (2006) memberikan contoh tes yang biasa digunakan untuk mengukur kemampuan berpikir kritis antara lain Assessment of Reasoning and Communication tes ini digunakan untuk ujian masuk di perguruan tinggi di Amerika. Tes ini meminta mahasiswa menulis 3 buah essay dan pidato pendek. Tes ini mengukur ketepatan, relevansi, kebijaksanaan, dan realisme dari jawaban mahasiswa. California Critical Thinking Skills Test: College Level (1990), yang dikembangkan oleh Peter Facione. Tes ini cocok untuk mahasiswa berbakat. Bentuk tes ini adalah pilihan ganda, menerjemahkan sesuatu, analisis argumen dan penaksiran, deduksi, puzzle, dan induksi yaitu penarikan kesimpulan. The California Critical Thinking Dispositions Inventory yang dikembangkan oleh Peter Facione and N. C. Facione yang mengarah pada penilaian individu, mengkritisi suatu informasi, dan dapat dilakukan secara berkelompok.

Pengetahuan-pengetahuan baru yang diperoleh mahasiswa diharapkan dapat dimanfaatkan mahasiswa untuk lebih mendalami materi-materi pelajaran sains yang dipelajari di sekolah dan dapat meningkatkan prestasi belajar mahasiswa. Salim (2002: 1190) menyebutkan pengertian prestasi adalah hasil yang diperoleh dari sesuatu yang dilakukan, sedangkan prestasi belajar adalah penguasaan pengetahuan keterampilan terhadap mata pelajaran yang dibuktikan melalui hasil tes. Prestasi belajar menggambarkan hasil penguasaan mahasiswa terhadap materi-materi yang telah dipelajari yang dapat dilihat dari aspek kognitif, psikomotorik, dan afektif.

Menurut Mulyasa (2005: 190) prestasi belajar merupakan hasil interaksi berbagai faktor. Faktor-faktor yang mempengaruhi proses dan hasil belajar dapat digolongkan menjadi empat yaitu bahan atau materi yang dipelajari, lingkungan, faktor instrumental, dan kondisi mahasiswa. Faktor-faktor tersebut akan memberikan kontribusi tertentu terhadap prestasi belajar. Berdasarkan pengertianpengertian di atas disimpulkan bahwa prestasi belajar adalah hasil yang didapatkan dari pembelajaran yang mengarah pada proses kognitif dan merupakan hasil interaksi dari beberapa faktor antara lain bahan atau materi yang dipelajari, lingkungan, faktor instrumental, dan kondisi mahasiswa. Krathwohl dan Anderson (2001) menjelaskan bahwa prestasi belajar mahasiswa dapat tercermin dalam dimensi proses kognitif mahasiswa. Dimensi proses kognitif ini meliputi enam tingkatan Taksonomi Bloom yang telah direvisi, yakni: mengingat (remember), memahami/mengerti (understand), menerapkan (apply), menganalisis (analyze), mengevaluasi (evaluate), dan menciptakan (create). Lebih lanjut Krathwohl dan Anderson (2001:66-88) memberikan penjelasan dari dimensi proses kognitif, yakni: 


\section{Mengingat}

Mengingat merupakan usaha mendapatkan kembali pengetahuan dari memori atau ingatan yang telah lampau, baik yang baru saja didapatkan maupun yang sudah lama didapatkan. Mengingat merupakan dimensi yang berperan penting dalam proses pembelajaran yang bermakna (meaningful learning) dan pemecahan masalah (problem solving). Kemampuan ini dimanfaatkan untuk menyelesaikan berbagai permasalahan yang jauh lebih kompleks. Mengingat meliputi mengenali (recognition) dan memanggil kembali (recalling). Mengenali berkaitan dengan mengetahui pengetahuan masa lampau yang berkaitan dengan hal-hal yang konkret, misalnya tanggal lahir, alamat rumah, dan usia, sedangkan memanggil kembali (recalling) adalah proses kognitif yang membutuhkan pengetahuan masa lampau secara cepat dan tepat.

\section{Memahami/mengerti}

Memahami/mengerti berkaitan dengan membangun sebuah pengertian dari berbagai sumber seperti pesan, bacaan dan komunikasi. Memahami/mengerti berkaitan dengan aktivitas mengklasifikasikan (classification) dan membandingkan (comparing). Mengklasifikasikan akan muncul ketika seorang mahasiswa berusaha mengenali pengetahuan yang merupakan anggota dari kategori pengetahuan tertentu. Mengklasifikasikan berawal dari suatu contoh atau informasi yang spesifik kemudian ditemukan konsep dan prinsip umumnya. Membandingkan merujuk pada identifikasi persamaan dan perbedaan dari dua atau lebih obyek, kejadian, ide, permasalahan, atau situasi. Membandingkan berkaitan dengan proses kognitif menemukan satu persatu ciri-ciri dari obyek yang diperbandingkan.

\section{Menerapkan}

Menerapkan menunjuk pada proses kognitif memanfaatkan atau mempergunakan suatu prosedur untuk melaksanakan percobaan atau menyelesaikan permasalahan. Menerapkan berkaitan dengan dimensi pengetahuan prosedural (procedural knowledge). Menerapkan meliputi kegiatan menjalankan prosedur (executing) dan mengimplementasikan (implementing). Menjalankan prosedur merupakan proses kognitif mahasiswa dalam menyelesaikan masalah dan melaksanakan percobaan di mana mahasiswa sudah mengetahui informasi tersebut dan mampu menetapkan dengan pasti prosedur apa saja yang harus dilakukan. Jika mahasiswa tidak mengetahui prosedur yang harus dilaksanakan dalam menyelesaikan permasalahan maka mahasiswa diperbolehkan melakukan modifikasi dari prosedur baku yang sudah ditetapkan.

Mengimplementasikan muncul apabila mahasiswa memilih dan menggunakan prosedur untuk hal-hal yang belum diketahui atau masih asing. Karena mahasiswa masih merasa asing dengan hal ini maka mahasiswa perlu mengenali dan memahami permasalahan terlebih dahulu kemudian baru menetapkan prosedur yang tepat untuk menyelesaikan masalah. Mengimplementasikan berkaitan erat dengan dimensi proses kognitif yang lain yaitu mengerti dan menciptakan. Menerapkan merupakan proses yang kontinu, dimulai dari mahasiswa menyelesaikan suatu permasalahan menggunakan prosedur baku/standar yang sudah diketahui. Kegiatan ini berjalan teratur sehingga mahasiswa benar-benar mampu melaksanakan prosedur ini dengan mudah, kemudian berlanjut pada munculnya permasalahan-permasalahan baru yang asing bagi mahasiswa, sehingga mahasiswa dituntut untuk mengenal dengan baik permasalahan tersebut dan memilih prosedur yang tepat untuk menyelesaikan permasalahan. 


\section{Menganalisis}

Menganalisis merupakan memecahkan suatu permasalahan dengan memisahkan tiap-tiap bagian dari permasalahan dan mencari keterkaitan dari tiaptiap bagian tersebut dan mencari tahu bagaimana keterkaitan tersebut dapat menimbulkan permasalahan. Kemampuan menganalisis merupakan jenis kemampuan yang banyak dituntut dari kegiatan pembelajaran di sekolah-sekolah. Berbagai mata pelajaran menuntut mahasiswa memiliki kemampuan menganalisis dengan baik. Tuntutan terhadap mahasiswa untuk memiliki kemampuan menganalisis sering kali cenderung lebih penting daripada dimensi proses kognitif yang lain seperti mengevaluasi dan menciptakan. Kegiatan pembelajaran sebagian besar mengarahkan mahasiswa untuk mampu membedakan fakta dan pendapat, menghasilkan kesimpulan dari suatu informasi pendukung.

Menganalisis berkaitan dengan proses kognitif memberi atribut (attributeing) dan mengorganisasikan (organizing). Memberi atribut akan muncul apabila mahasiswa menemukan permasalahan dan kemudian memerlukan kegiatan membangun ulang hal yang menjadi permasalahan. Kegiatan mengarahkan mahasiswa pada informasi-informasi asal mula dan alasan suatu hal ditemukan dan diciptakan. Mengorganisasikan menunjukkan identifikasi unsurunsur hasil komunikasi atau situasi dan mencoba mengenali bagaimana unsurunsur ini dapat menghasilkan hubungan yang baik. Mengorganisasikan memungkinkan mahasiswa membangun hubungan yang sistematis dan koheren dari potongan-potongan informasi yang diberikan. Hal pertama yang harus dilakukan oleh mahasiswa adalah mengidentifikasi unsur yang paling penting dan relevan dengan permasalahan, kemudian melanjutkan dengan membangun hubungan yang sesuai dari informasi yang telah diberikan.

\section{Mengevaluasi}

Evaluasi berkaitan dengan proses kognitif memberikan penilaian berdasarkan kriteria dan standar yang sudah ada. Kriteria yang biasanya digunakan adalah kualitas, efektivitas, efisiensi, dan konsistensi. Kriteria atau standar ini dapat pula ditentukan sendiri oleh mahasiswa. Standar ini dapat berupa kuantitatif maupun kualitatif serta dapat ditentukan sendiri oleh mahasiswa. Perlu diketahui bahwa tidak semua kegiatan penilaian merupakan dimensi mengevaluasi, namun hampir semua dimensi proses kognitif memerlukan penilaian. Perbedaan antara penilaian yang dilakukan mahasiswa dengan penilaian yang merupakan evaluasi adalah pada standar dan kriteria yang dibuat oleh mahasiswa. Jika standar atau kriteria yang dibuat mengarah pada keefektifitasan hasil yang didapatkan dibandingkan dengan perencanaan dan keefektifan prosedur yang digunakan maka apa yang dilakukan mahasiswa merupakan kegiatan evaluasi.

Evaluasi meliputi mengecek (checking) dan mengkritisi (critiquing). Mengecek mengarah pada kegiatan pengujian hal-hal yang tidak konsisten atau kegagalan dari suatu operasi atau produk. Jika dikaitkan dengan proses berpikir merencanakan dan mengimplementasikan maka mengecek akan mengarah pada penetapan sejauh mana suatu rencana berjalan dengan baik. Mengkritisi mengarah pada penilaian suatu produk atau operasi berdasarkan pada kriteria dan standar eksternal. Mengkritisi berkaitan erat dengan berpikir kritis. Mahasiswa melakukan penilaian dengan melihat sisi negatif dan positif dari suatu hal, kemudian melakukan penilaian menggunakan standar ini. 


\section{Menciptakan}

Menciptakan mengarah pada proses kognitif meletakkan unsur-unsur secara bersama-sama untuk membentuk kesatuan yang koheren dan mengarahkan mahasiswa untuk menghasilkan suatu produk baru dengan mengorganisasikan beberapa unsur menjadi bentuk atau pola yang berbeda dari sebelumnya. Menciptakan sangat berkaitan erat dengan pengalaman belajar mahasiswa pada pertemuan sebelumnya. Meskipun menciptakan mengarah pada proses berpikir kreatif, namun tidak secara total berpengaruh pada kemampuan mahasiswa untuk menciptakan. Menciptakan di sini mengarahkan mahasiswa untuk dapat melaksanakan dan menghasilkan karya yang dapat dibuat oleh semua mahasiswa. Perbedaan menciptakan ini dengan dimensi berpikir kognitif lainnya adalah pada dimensi yang lain seperti mengerti, menerapkan, dan menganalisis mahasiswa bekerja dengan informasi yang sudah dikenal sebelumnya, sedangkan pada menciptakan mahasiswa bekerja dan menghasilkan sesuatu yang baru.

Menciptakan meliputi menggeneralisasikan (generating) dan memproduksi (producing). Menggeneralisasikan merupakan kegiatan merepresentasikan permasalahan dan penemuan alternatif hipotesis yang diperlukan. Menggeneralisasikan ini berkaitan dengan berpikir divergen yang merupakan inti dari berpikir kreatif. Memproduksi mengarah pada perencanaan untuk menyelesaikan permasalahan yang diberikan. Memproduksi berkaitan erat dengan dimensi pengetahuan yang lain yaitu pengetahuan faktual, pengetahuan konseptual, pengetahuan prosedural, dan pengetahuan metakognisi.

Prestasi belajar masing-masing mahasiswa tidak sama, meskipun mahasiswa-mahasiswa tersebut berada dalam kelas dengan dosen pengajar yang sama, dan mendengarkan materi yang sama pula. Perbedaan prestasi belajar mahasiswa ini dipengaruhi oleh beberapa faktor yaitu faktor internal dan faktor eksternal. Faktor internal adalah faktor yang dimiliki oleh mahasiswa atau faktor yang tumbuh dalam diri mahasiswa. Tim Pengembangan MKDK IKIP Semarang mengungkapkan faktor-faktor yang mempengaruhi prestasi mahasiswa adalah kondisi fisiologis, yang meliputi kesehatan tubuh dan gizi yang diterima oleh mahasiswa dan kondisi psikologis yang meliputi kematangan perkembangan hasil pertumbuhan jasmani, kecerdasan, motivasi belajar, kesiapan atau kesediaan individu untuk berbuat sesuatu, bakat dan minat, sikap yaitu kecenderungan melakukan respons dengan proses belajar dan perkembangan kehidupan, dan kemampuan kognitif yaitu kemampuan penalaran terhadap sesuatu (Efiana, 2006: 27-28).

Berkaitan dengan kecerdasan atau intelegensi Mulyasa (2005:193) berpendapat bahwa intelegensi merupakan salah satu faktor yang berpengaruh terhadap tinggi rendahnya prestasi belajar. Intelegensi berperan sebagai dasar potensial pencapaian hasil belajar, artinya hasil belajar yang diperoleh mahasiswa tidak akan melebihi intelegensinya. Semakin tinggi tingkat intelegensi mahasiswa maka semakin besar pula kemungkinan tingkat hasil belajar yang dicapai. Meskipun demikian tidak dapat dikatakan bahwa prestasi mahasiswa kurang karena tingkat intelegensinya juga kurang, karena masih banyak faktor lain yang mempengaruhi. Minat juga mempengaruhi prestasi belajar mahasiswa. Jika seorang mahasiswa berminat terhadap materi yang diberikan oleh dosen maka mahasiswa akan termotivasi dan belajar lebih keras sehingga terdapat kemungkinan prestasi belajarnya juga akan bagus. 
Prestasi belajar mahasiswa dipengaruhi oleh waktu (time) dan kesempatan (engagement). Waktu dan kesempatan yang dimiliki oleh masing-masing mahasiswa berbeda sehingga berpengaruh terhadap perbedaan prestasi belajar mahasiswa. Mahasiswa yang memberikan lebih banyak waktu dan kesempatan untuk belajar cenderung memiliki prestasi belajar yang baik. Tingkat kepandaian seseorang sangat ditentukan dengan waktu dan kesempatan. Mahasiswa akan mampu mengerjakan tugas dengan lebih baik jika diberikan waktu dan kesempatan yang cukup. Mahasiswa yang lebih pandai memiliki kemungkinan mengerjakan tugas lebih singkat daripada mahasiswa yang kurang pandai, sehingga, dosen harus memiliki kemampuan mengajar mahasiswa secara individual dan mengenali karakteristik masing-masing mahasiswa sehingga kegiatan pembelajaran dapat berjalan secara optimal. Prestasi belajar dapat diukur dengan menggunakan tes prestasi yang mengukur dimensi proses kognitif. Tes prestasi dapat berbentuk essay maupun objektif. Hendaknya dosen dapat menentukan jenis tes yang digunakan menyesuaikan dengan kebutuhan mahasiswa. Dimensi proses kognitif yang dijadikan standar dalam mengukur tes prestasi belajar sains menggunakan Taksonomi Bloom yang telah direvisi antara lain mengingat (remember), memahami/mengerti (understand), menerapkan (apply), menganalisis (analyze), mengevaluasi (evaluate), dan menciptakan (create)

\section{B. Metode Penelitian}

Desain penelitian dipergunakan untuk mempersiapkan kegiatan penelitian agar peneliti dapat memperoleh data yang sahih dan sesuai dengan variabel dan tujuan penelitian. Penelitian ini menggunakan model penelitian deskriptif korelasional. Setyadin (2005) menyatakan bahwa penelitian deskriptif merupakan penelitian yang bertujuan untuk menggambarkan karakteristik frekuensi dan distribusinya. Penelitian deskriptif bermaksud untuk mendalami lebih jauh suatu masalah. Karakteristik penelitian dan distribusi frekuensi diperoleh berdasarkan hasil analisis instrumen penelitian. Arikunto (1998) menyatakan bahwa penelitian korelasi bertujuan untuk menemukan hubungan antara beberapa variabel, dan bila terdapat hubungan pada variabel-variabel yang diteliti dapat diketahui erat tidaknya hubungan yang ada dan berarti tidaknya hubungan yang ada pada variabel-variabel yang diteliti.

Penelitian ini memiliki tujuan untuk mengetahui hubungan tiga variabel yang diukur secara kuantitatif. Ketiga variabel dicari hubungannya satu dengan lainnya. Adanya koefisien korelasi dapat membandingkan hasil pengukuran antara tiga variabel agar dapat menentukan tingkat hubungan antara ketiga variabel tersebut (Arikunto, 1998). Variabel kemampuan berpikir kreatif mahasiswa ( $\left.\mathrm{X}_{1}\right)$ dan kemampuan berpikir kritis mahasiswa $\left(\mathrm{X}_{2}\right)$ sebagai variabel prediktor akan dicari secara berurutan tingkat hubungannya dengan variabel kriterium yaitu prestasi belajar sains (Y). Model rancangan penelitian diilustrasikan Gambar 3.1.

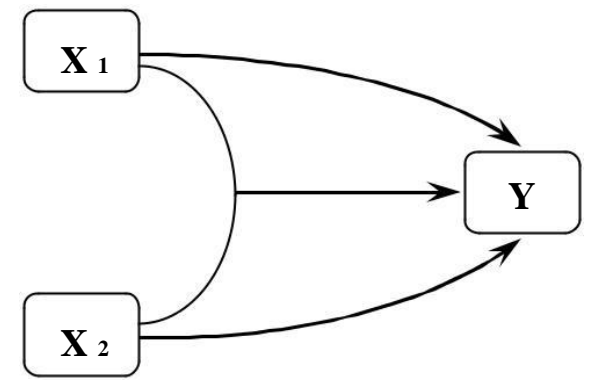

$$
\begin{aligned}
& \text { Keterangan: } \\
& \begin{aligned}
\mathrm{X}_{1}= & \text { kemampuan berpikir } \\
& \text { kreatif } \\
\mathrm{X}_{2}= & \text { kemampuan berpikir } \\
& \text { kritis } \\
\mathrm{Y}= & \text { prestasi belajar }
\end{aligned}
\end{aligned}
$$

Gambar 1 Rancangan Penelitian 
Chao menyebutkan bahwa populasi disebut dengan istilah parameter atau universe yaitu segala sesuatu yang berkaitan dengan keseluruhan sumber data potensial dalam acuan atau lingkup penelitian yang ditetapkan (Setyadin, 2005:17). Sedangkan Tuckman menyebutkan bahwa population is the target group of the study (Setyadin, 2005:17). Populasi merupakan keseluruhan objek atau subjek sumber informasi yang diteliti. Populasi dapat berupa orang, benda, tumbuhan, peristiwa, dan gejala yang memiliki ciri-ciri tertentu dan jelas (Wiyono, 2004:29). Populasi adalah kelompok yang menjadi target penelitian. Berdasarkan pengertian di atas dapat disimpulkan bahwa populasi merupakan target penelitian yang dapat berupa benda, makhluk, dan peristiwa yang memiliki ciri-ciri tertentu dan jelas yang merupakan sumber data dalam lingkup penelitian.

Penelitian ini meneliti elemen yang ada dalam wilayah penelitian, sehingga disebut dengan penelitian populasi. Populasi dapat berupa populasi berhingga yaitu populasi yang dapat dihitung dan populasi tak hingga atau populasi yang tidak dapat dihitung. Setyadin (2005:17) menyatakan bahwa populasi berhingga memiliki ciri dapat dihitung secara pasti, sedangkan populasi tak hingga memiliki ciri tidak dapat dihitung secara pasti namun jumlahnya subyek dapat diperkirakan. Populasi dalam penelitian ini adalah populasi berhingga. Subyek dalam penelitian ini adalah mahasiswa semester dua Prodi PGSD FIP IKIP PGRI MADIUN.

Sampel adalah bagian dari populasi yang mewakili populasi tersebut dan memiliki karakteristik tertentu yang disebut dengan nilai statistik (Setyadin, 2005). Pengambilan sampel atau yang biasa disebut sampling memiliki teknikteknik tertentu. Berdasarkan pendapat tersebut, jumlah populasi sebanyak 366 orang mahasiswa, diambil sampel penelitian sebanyak 191 orang mahasiswa. Jumlah sampel ini diperoleh berdasarkan rumus Slovin, dimana perhitungan ukuran sampel itu didasarkan atas kesalahan 5\% dan memiliki taraf kepercayaan 95\% terhadap populasi (Sugiyono, 2005:89). Adapun rumus Slovin sebagai penentuan jumlah sampel adalah:

$\mathrm{n}=\frac{\mathrm{N}}{\mathrm{Nd}^{2}+1}$

Keterangan:

$\mathrm{n}=$ Jumlah responden,

$\mathrm{N}=$ Jumlah total responden,

$\mathrm{d}^{2}=$ Presisi, ditetapkan 5\% dengan tingkat kepercayaan 95\% (Riduwan dan Kuncoro, 2007:49).

Teknik proporsional random sampling untuk menentukan besarnya sampel di setiap program studi. Winarsunu (2002:138) menyatakan bahwa proporsional random sampling digunakan karena karakteristik populasi terdiri dari kategori, kelompok, atau golongan yang setara atau sejajar yang diduga kuat berpengaruh pada hasil penelitian. Penentuan jumlah sampel tiap kelas menggunakan rumus (Riduwan dan Kuncoro, 2007:52) yaitu:

$\mathrm{n}_{\mathrm{i}}=\frac{\mathrm{N}}{\mathrm{N}^{\mathrm{i}} \times \mathrm{S}}$ 
Keterangan:

$\mathrm{n}_{\mathrm{i}}=$ Jumlah sampel perkelas, $\mathrm{N}_{\mathrm{i}}=$

Jumlah populasi perkelas,

$\mathrm{N}=$ Jumlah populasi keseluruhan,

$\mathrm{S}=$ Jumlah sampel yang diambil sesuai dengan rumus Slovin.

Perhitungan besar sampel secara proporsional dan hasilnya untuk tiap program studi, dapat dilihat dalam Tabel 3.1.

Tabel 1 Jumlah Populasi dan Sampel Penelitian

\begin{tabular}{llcc}
\hline No & Kelas & Jumlah Populasi & Jumlah Sampel \\
\hline 1 & II offering A & 42 orang & 22 orang \\
2 & II offering B & 39 orang & 20 orang \\
3 & II offering C & 43 orang & 22 orang \\
4 & II offering D & 42 orang & 22 orang \\
5 & II offering E & 39 orang & 20 orang \\
6 & II offering F & 40 orang & 21 orang \\
7 & II offering G & 41 orang & 21 orang \\
8 & II offering H & 39 orang & 20 orang \\
9 & II offering I & 41 orang & 21 orang \\
\hline & Jumlah total & $\mathbf{3 6 6}$ orang & $\mathbf{1 9 1}$ orang \\
\hline
\end{tabular}

Teknik pengumpulan data dalam penelitian ini adalah dengan menggunakan teknik tes. Tes merupakan pertanyaan-pertanyaan atau latihan atau alat lain yang digunakan untuk mengukur keterampilan, pengetahuan, intelegensi, kemampuan, atau bakat yang dimiliki oleh individu atau kelompok (Arikunto, 1998:139). Instrumen penelitian yang akan digunakan dalam penelitian ini adalah tes. Azwar (2007) menyatakan bahwa berdasarkan dari wujud fisiknya suatu tes merupakan sekumpulan pertanyaan yang harus dijawab dan atau tugas yang harus dikerjakan yang akan memberikan informasi tentang aspek psikologis tertentu berdasarkan jawaban terhadap pertanyaan-pertanyaan atau cara dan hasil subyek dalam melakukan tugas-tugas tersebut.

Anastasi menyatakan bahwa tes merupakan pengukuran yang obyektif dan standar terhadap sampel perilaku (Azwar, 2007). Berdasarkan pengertianpengertian di atas dapat ditarik kesimpulan bahwa tes merupakan pertanyaanpertanyaan atau latihan-latihan atau tugas-tugas yang harus dikerjakan untuk mendapatkan informasi tentang aspek psikologis tertentu yang diukur secara obyektif dan standar terhadap sampel penelitian. Jenis tes yang diberikan kepada mahasiswa (sampel) berbentuk tes berpikir kreatif, tes berpikir kritis, dan tes prestasi yang diberikan kepada mahasiswa pada kegiatan pembelajaran. Tes yang mengukur kemampuan berpikir kreatif menggunakan subvariabel pedoman Munandar yang memanfaatkan perilaku kreatif yaitu kelancaran (fluency), kerincian (elaboration), fleksibilitas (flexibility), dan orisinalitas (originality).

Tes yang mengukur kemampuan berpikir kritis merupakan tes yang menggunakan subvariabel yang dikembangkan dari Marzano yang meliputi kemampuan memfokuskan masalah, kemampuan mengingat, memperoleh informasi, mengingat, menganalisis, dan mengevaluasi. Sedangkan tes untuk mengukur prestasi belajar sains merupakan tes sumatif yang mengukur kemampuan berpikir kognitif mahasiswa dengan subvariabel yang dikembangkan oleh 
Krathwohl dan Anderson yang merupakan dimensi berpikir kognitif yang terdiri dari mengingat (recalling), mengerti/memahami (understand), mengaplikasikan (apply), menganalisis (analyze), mengevaluasi (evaluate), dan menciptakan (create) yang merupakan revisi dari Taksonomi Bloom yang disebut dengan Ranah Kognitif. Tes sumatif dipilih karena dengan menggunakan tes jenis ini tingkat prestasi mahasiswa dapat dengan mudah diukur dan mudah dalam melakukan penilaian. Selain itu variabel prestasi yang diukur dibatasi dan merupakan variabel yang mengukur kemampuan kognitif.

Bentuk tes yang mengukur kemampuan berpikir kreatif merupakan soal tes yang menuntut mahasiswa untuk dapat menemukan alternatif jawaban sendiri yang berbeda dari sebuah soal, sedangkan untuk tes yang mengukur kemampuan berpikir kritis menggunakan tes yang menuntut mahasiswa untuk dapat memecahkan masalah yang diberikan. Bentuk tes yang diberikan adalah bentuk tes uraian sehingga dapat mengukur kemampuan berpikir kreatif dan kritis secara lebih akurat. Soal uraian untuk mengukur kemampuan berpikir kreatif dan kritis dipilih karena memiliki keunggulan yaitu mudah disiapkan dan disusun, dapat mendorong mahasiswa untuk berani mengemukakan pendapat, dapat mengetahui sejauh mana mahasiswa mendalami suatu permasalahan yang diteskan.

Instrumen tes prestasi memilih bentuk soal tertulis yang berupa pilihan ganda. Soal berbentuk pilihan ganda dipilih karena dengan bentuk tes ini dapat mengukur berbagai macam aspek materi, memiliki keterandalan yang cukup tinggi (semakin banyak jumlah distraktornya semakin tinggi keterandalannya), kesahihannya lebih tinggi (faktor menebak dapat dihindarkan), dan dapat menjangkau semua bentuk tingkatan dimensi proses kognitif. Ketentuan pemberian skor instrumen tes berpikir kreatif untuk pengambilan data menggunakan kriteria yang diperoleh dari hasil uji coba. Hal ini dilakukan karena mahasiswa memiliki kemampuan memberikan variasi jawaban yang berbeda-beda untuk masing-masing butir soal pertanyaan. Pada butir soal tertentu terdapat kemungkinan mahasiswa mampu memberikan banyak variasi jawaban, sedangkan pada butir soal yang lain kemungkinan mahasiswa hanya mampu memberikan beberapa alternatif jawaban.

Ketentuan pemberian skor instrumen berpikir kritis menggunakan kisi-kisi instrumen tes berpikir kritis yang dijabarkan dari indikator-indikator variabel. Skor memiliki rentang 1 sampai dengan 4. Tingkat prestasi belajar sains ditentukan dari hasil skor tes yang diberikan kepada responden. Instrumen tes berbentuk pilihan ganda. Skor dihitung dari jumlah jawaban yang benar pada setiap butir soal tes yang diberikan, kemudian nilai skor dipilih dengan menggunakan rumus:

$S=R-W$

Keterangan:

$\mathrm{S}=$ Skor,

$\mathrm{R}=$ Skor Ideal,

$\mathrm{W}$ = Jawaban salah (Arikunto, 2002).

Wiersma menyatakan bahwa yang disebut dengan variabel penelitian adalah suatu rumusan dari konsep yang memiliki karakteristik nilai berbeda untuk masing-masing individu dan memiliki dua atau lebih nilai (Setyadin, 2005:13). Variabel dalam penelitian ini adalah kemampuan berpikir kreatif mahasiswa $\left(\mathrm{X}_{1}\right)$, kemampuan berpikir kritis (X2), dan prestasi belajar (Y). Tiap variabel dijabarkan menjadi subvariabel dan tiap subvariabel akan dijabarkan menjadi indikator yang 
akan diukur. Jabaran indikator akan dibuat menjadi acuan untuk pembuatan butirbutir pertanyaan tes untuk mengukur kemampuan berpikir kreatif, kemampuan berpikir kritis, dan prestasi belajar.

Analisis data adalah salah satu bagian dari metode penelitian untuk memberikan makna terhadap data yang diperoleh sehingga peneliti dapat menjawab permasalahan yang diajukan dalam penelitian. Teknik analisis data dalam penelitian ini menggunakan teknik analisis perhitungan statistik yang datanya berupa data kuantitatif. Penelitian ini menggunakan analisis data kuantitatif yang berupa deskriptif korelasional dan regresi ganda. Teknik analisis deskriptif dilakukan untuk mendeskripsikan kemampuan berpikir kreatif, kemampuan berpikir kritis, dan prestasi belajar sains. Tingkat hubungan antara ketiga variabel yang diteliti dapat diketahui dari nilai koefisien korelasi. Koefisien korelasi dapat membandingkan hasil pengukuran antara tiga variabel sehingga dapat mengetahui tingkat hubungan antara ketiga variabel (Arikunto, 1998:251).

Variabel kemampuan berpikir kreatif $\left(\mathrm{X}_{1}\right)$ dan variabel kemampuan berpikir kritis $\left(\mathrm{X}_{2}\right)$ sebagai variabel bebas akan dicari secara berurutan tingkat hubungannya dengan variabel terikat yaitu prestasi belajar sains (Y), kemudian dilakukan analisis uji asumsi linieritas, normalitas, dan homogenitas. Jika ketiga asumsi terpenuhi maka dianalisis regresi ganda untuk mendapatkan sumbangan efektif dan sumbangan relatif masing-masing variabel prediktor terhadap variabel kriterium.

Analisis regresi ganda merupakan teknik analisis statistik parametrik yang digunakan untuk menguji variasi variabel kriterium oleh beberapa variabel prediktor. Penelitian ini memiliki variabel prediktor $1\left(\mathrm{X}_{1}\right)$ kemampuan berpikir kreatif, variabel prediktor $2\left(\mathrm{X}_{2}\right)$ kemampuan berpikir kritis, dan variabel kriterium

(Y) prestasi belajar sains. Analisis regresi digunakan untuk menemukan koefisien beta dari hubungan variabel bebas (prediktor) kemampuan berpikir kreatif ( $\left.\mathrm{X}_{1}\right)$ dan kritis $\left(\mathrm{X}_{2}\right)$ dengan variabel terikat (kriterium) prestasi belajar sains (Y) melalui rumus:

$\mathrm{Y}=\beta_{0}+\beta_{1} \mathrm{X}_{1}+\beta_{2} \mathrm{X}_{2}$

Keterangan:

$\mathrm{Y}=$ kriterium,

$\beta_{0}=$ bilangan konstanta (beta 0 ),

$\beta_{1}=$ bilangan konstanta $\mathrm{X}_{1}$ (beta $\mathrm{X}_{1}$ ),

$\mathrm{X}_{1}=$ bilangan prediktor 1 ,

$\beta_{2}=$ bilangan konstanta $\mathrm{X}_{2}\left(\right.$ beta $\left.\mathrm{X}_{2}\right)$,

$\mathrm{X}_{2}$ = bilangan prediktor 2 (Draper, 1998).

Analisis regresi dilakukan dengan program komputer SPSS PASW Statistics

18. Langkah-langkah analisis regresi adalah:

a. Mencari persamaan regresi

b. Menghitung Koefisien determinasi $\left(\mathrm{R}^{L}\right)$ dengan persamaan

$$
R_{2}=\frac{\left(\beta_{1} . \Sigma x_{1} y\right)+\left(\beta_{2} \cdot \Sigma x_{2} y\right)}{2}
$$

c. Menghitung residu atau kesalahan ramalan (Res)

$\operatorname{Res}=\left(1-\mathrm{R}^{2}\right)\left(\sum \mathrm{y}^{2}\right)$ 
d. Menghitung taraf korelasi (r)

$$
r=\sqrt{\frac{\left(\beta_{1} . \Sigma x_{1} y\right)+\left(\beta_{2} . \Sigma x_{2} y\right)}{2}} \text { atau } \sqrt{R^{2}}
$$

e. Menghitung harga $\mathrm{F}$ regresi

$$
\begin{aligned}
& F=\frac{R^{2}(N-m-1)}{m\left(1-R^{2}\right)} \\
& \text { Dengan: } \\
& \mathrm{N}=\text { Jumlah sampel } \\
& \mathrm{m}=\text { Jumlah prediktor }=2
\end{aligned}
$$

f. Menghitung Sumbangan Relatif (SR) dan Sumbangan Efektif (SE)

Winarsunu (2002:209-210) menjelaskan bahwa sumbangan efektif dan sumbangan relatif merupakan ukuran seberapa besar variabel prediktor dalam analisis regresi memiliki kontribusi terhadap variabel kriterium. Sumbangan relatif menunjukkan ukuran besarnya sumbangan suatu prediktor terhadap jumlah kuadrat regresi, sedangkan sumbangan efektif menunjukkan ukuran sumbangan suatu prediktor terhadap keseluruhan efektivitas garis regresi yang digunakan sebagai dasar prediksi. Sebelum menentukan besarnya sumbangan relatif dan efektif dibuat Tabel Kerja Anareg. Menentukan sumbangan efektif dan sumbangan relatif menggunakan rumus:

$$
\begin{aligned}
& S R=\frac{\beta\left(\sum_{12} y\right)}{J K_{r e g}} \times 100 \% \\
& S E_{x 12}=\left(S R_{x 12}\right)\left(R^{2}\right)
\end{aligned}
$$

Keterangan:

$\mathrm{SR} \quad=$ Sumbangan Relatif;

$\mathrm{JK}_{\text {reg }}=$ Jumlah Kuadrat Regresi / Sum of Square;

$\mathrm{SE} \quad=$ Sumbangan Efektif.

\section{Hasil Dan Pembahasan}

Penelitian yang menguji hipotesis berisi mengenai hasil-hasil yang diperoleh yakni memuat uraian tentang karakteristik masing-masing variabel dan memuat uraian tentang hasil pengujian hipotesis. Deskripsi data merupakan penjabaran data hasil penelitian dari masing-masing variabel. Variabel yang diteliti dalam penelitian ini adalah variabel kemampuan berpikir kreatif (X1), kemampuan berpikir kritis (X2), dan variabel prestasi belajar (Y). Setelah melakukan pendeskripsian data, langkah selanjutnya ialah melakukan analisis data. Analisis data dalam penelitian ini menggunakan bantuan program komputer SPSS PASW Statistics 18. Teknik analisis yang dilakukan adalah analisis persentase dan regresi ganda. Langkah yang diperlukan dalam melakukan analisis data yaitu melakukan penyekoran terhadap jawaban yang diberikan oleh sampel penelitian dengan memberikan skor sesuai dengan kriteria yang telah ditetapkan untuk setiap variabel. Langkah selanjutnya ialah melakukan tabulasi data.

\section{Hasil Penelitian}

Tabulasi data merupakan langkah memasukkan skor yang dihasilkan sampel dalam masing-masing variabel ke dalam tabel. Tabulasi data memanfaatkan program komputer Microsoft Office Excel 2007. Setelah melakukan tabulasi data 
selanjutnya menentukan distribusi frekuensi dan hasil yang didapatkan digambarkan dalam bentuk diagram balok, menentukan mean, simpangan baku, dan menentukan persentase. Menggambarkan grafik hasil analisis persentase bertujuan untuk menunjukkan seberapa tinggi kemampuan berpikir kreatif, kemampuan berpikir kritis, dan prestasi belajar mahasiswa pada matakuliah Konsep Sains II Prodi PGSD IKIP PGRI MADIUN. Deskripsi data masing-masing variabel kemampuan berpikir kreatif, berpikir kritis, dan prestasi belajar sebagai berikut.

\section{a. Variabel Kemampuan Berpikir Kreatif}

Lebar kelas interval data kemampuan berpikir kreatif adalah 3 dihitung dengan persamaan berikut.

$\mathrm{i}=\frac{\mathrm{R}}{\mathrm{k}}=\frac{\text { (skor tertinggi }- \text { skor terendah) }}{9}$

$\mathrm{i}=\frac{25-0}{9}=\frac{25}{9}=2,93$ dibulatkan menjadi 3

Diagram balok dari hasil distribusi freknensi variabel berpikir kreatif dapat dilihat pada Gambar 2.

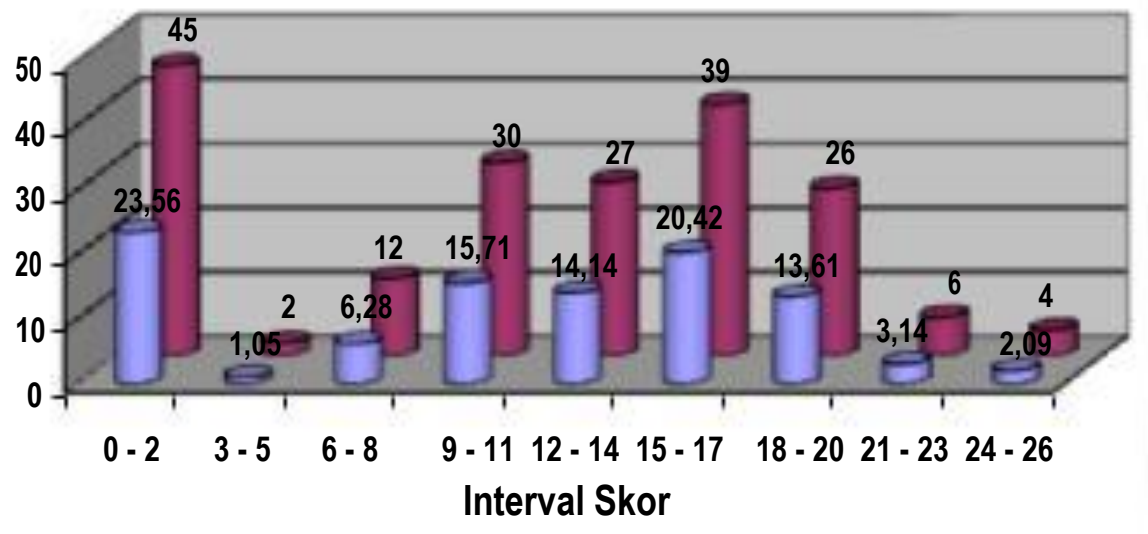

Gambar 2 Diagram Balok Distribusi Frekuensi Variabel Kemampuan Berpikir Kreatif

Berdasarkan Gambar 2 menunjukkan bahwa dari 191 mahasiswa yang berada dalam interval skor: 0 s.d. 2 dengan frekuensi 45 (23,56\%); 3 s.d. 5 dengan frekuensi 2 orang (1,05\%); 6 s.d. 8 dengan frekuensi 12 orang (6,28\%); 9 s.d. 11 dengan frekuensi 30 orang $(15,71 \%) ; 12$ s.d. 14 dengan frekuensi 27 orang $(14,14 \%) ; 15$ s.d. 17 dengan frekuensi 39 orang $(20,42 \%) ; 18$ s.d. 20 dengan frekuensi 26 orang (13,61\%); 21 s.d. 23 dengan frekuensi 6 orang $(3,14 \%)$; dan 24 s.d. 26 dengan frekuensi 4 orang $(2,09 \%)$. Berdasarkan hasil analisis deskriptif didapatkan nilai mean variabel kemampuan berpikir kreatif adalah 10,94 dengan simpangan baku 7,296. Perolehan skor dalam persentase adalah 39,07\% dari skor total ideal dihitung dengan persamaan berikut.

$\mathrm{P}=\frac{\bar{X}}{\text { skor ideal }} \times 100=\frac{10,94}{28} \times 100 \%=39,07 \%$

\section{b. Variabel Kemampuan Berpikir Kritis}

Lebar kelas interval data kemampuan berpikir kritis adalah 5 dihitung dengan persamaan berikut. 
$\mathrm{i}=\frac{\mathrm{R}}{\mathrm{k}}=\frac{\text { (skor tertinggi }- \text { skor terendah) }}{9}$

$\mathrm{i}=\frac{39-0}{9}=\frac{39}{9}=4,6$ dibulatkan menjadi 5

Diagram balok dari hasil distribusi frekuensi variabel kemampuan berpikir kritis dapat dilihat pada Gambar 3.

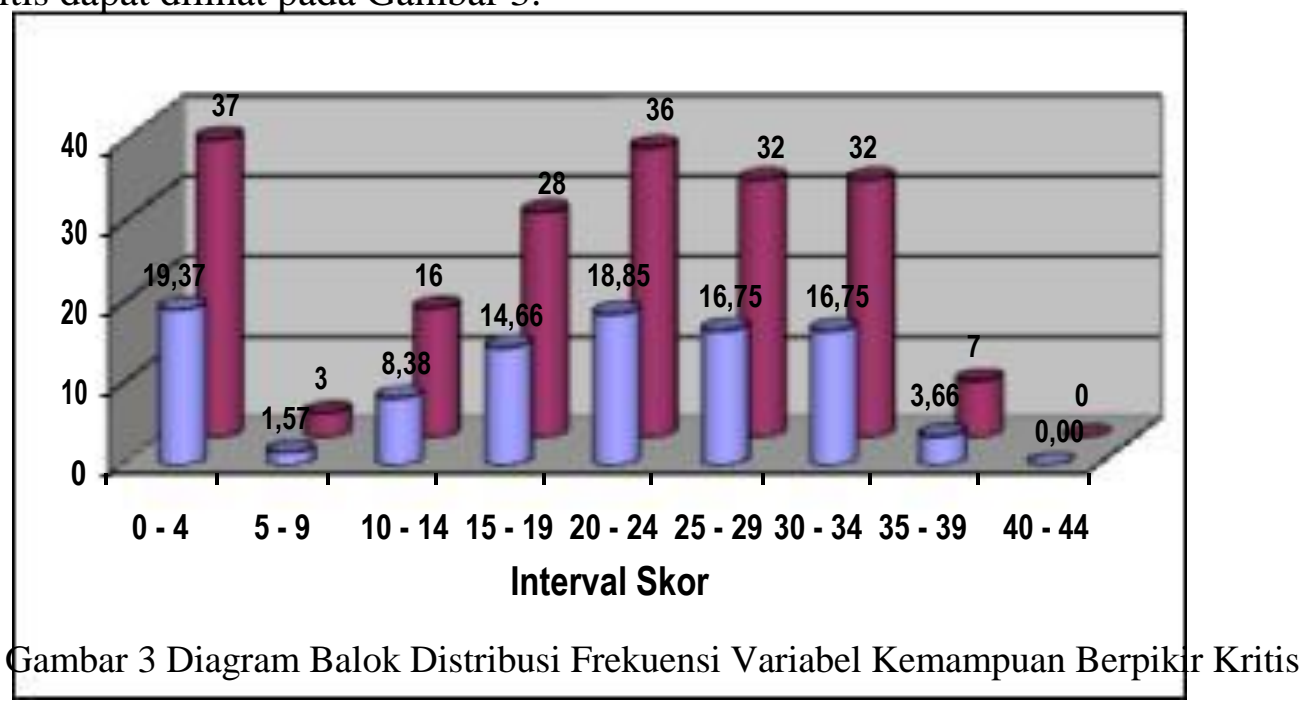

Berdasarkan Gambar 3 menunjukkan bahwa dari 191 mahasiswa yang berada dalam interval skor: 0 s.d. 4 dengan frekuensi 37 orang $(19,37 \%)$; 5 s.d. 9 dengan frekuensi 3 orang $(1,75 \%)$; 10 s.d. 14 dengan frekuensi 16 orang $(8,38 \%)$; 15 s.d. 19 dengan frekuensi 28 orang (14,66\%); 20 s.d. 24 dengan frekuensi 36 orang $(18,85 \%) ; 25$ s.d. 29 dengan frekuensi 32 orang $(16,75 \%) ; 30$ s.d. 34 dengan frekuensi 32 orang $(16,75 \%) ; 35$ s.d. 39 dengan frekuensi 7 orang $(3,66 \%)$; dan 40 s.d. 44 dengan frekuensi $0(0 \%)$. Berdasarkan hasil analisis deskriptif didapatkan nilai mean variabel kemampuan berpikir kritis adalah 19,15 dengan simpangan baku 11,611. Perolehan skor dalam persentase adalah 30,53\% dari skor total ideal dihitung dengan persamaan berikut.

$\mathrm{P}=\frac{\bar{X}}{\text { skor ideal }} \times 100 \%=\frac{19,15}{60} \times 100 \%=31,92 \%$

\section{c. Prestasi Belajar}

Lebar kelas interval data prestasi belajar adalah 0,94 dihitung dengan persamaan berikut.

$\mathrm{i}=\frac{\mathrm{R}}{\mathrm{k}}=\frac{\text { (skor tertinggi }- \text { skor terendah) }}{9}$

$\mathrm{i}=\frac{8}{9}^{-0} \equiv 8=0,94$

Diagram balok dari hasil distribusi frekuensi variabel prestasi belajar dapat dilihat pada Gambar 4. 


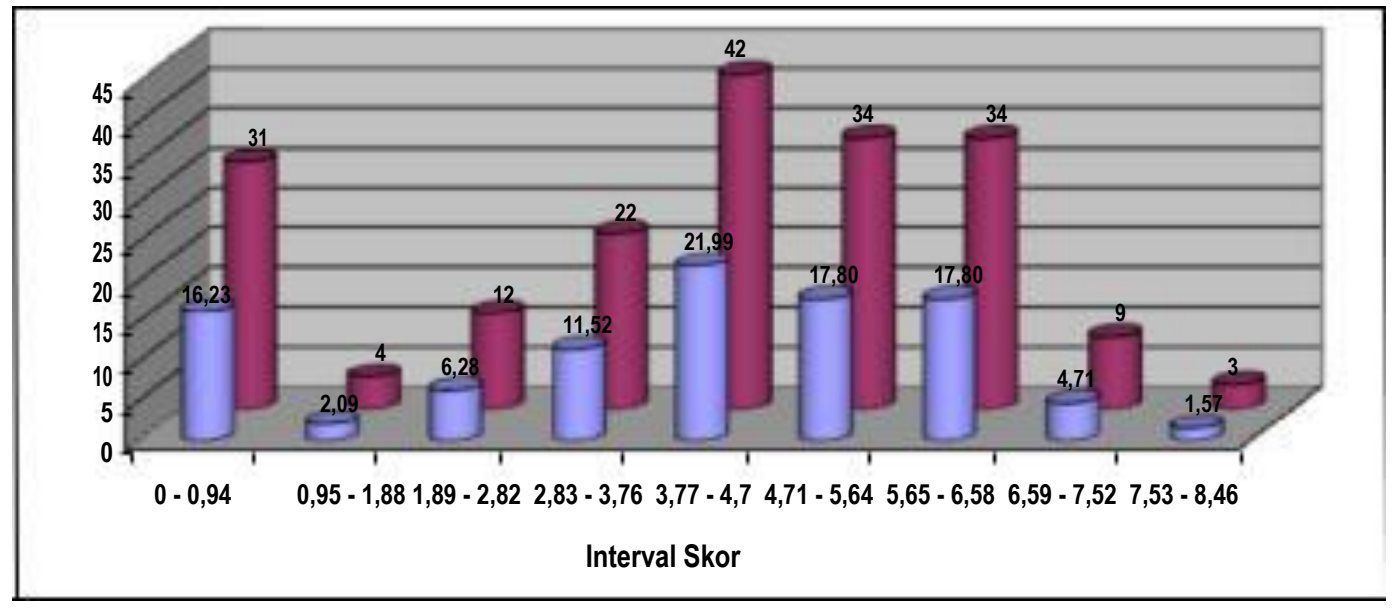

Gambar 4 Diagram Balok Distribusi Frekuensi Variabel Prestasi Belajar

Berdasarkan Gambar 4 menunjukkan bahwa dari 191 mahasiswa yang berada dalam interval skor: 0 s.d. 0,94 dengan frekuensi 31 orang (16,23\%); 0,95 s.d. 1,88 dengan frekuensi 4 orang (2,09); 1,89 s.d. 2,82 dengan frekuensi 12 orang $(6,28 \%) ; 2,83$ s.d. 3,76 dengan frekuensi 22 orang (11,52\%); 3,77 s.d. 4,7 dengan frekuensi 42 orang (21,99\%); 4,71 s.d. 5,64 dengan frekuensi 34 orang (17,8\%); 5,65 s.d. 6,58 dengan frekuensi 34 orang (17,8\%); 6,59 s.d. 7,52 dengan frekuensi 9 orang (4,71\%); dan 7,53 s.d. 8,46 dengan frekuensi 3 orang (1,57\%). Berdasarkan hasil analisis deskriptif didapatkan nilai mean variabel prestasi belajar adalah 3,79 dengan simpangan baku 2,167. Perolehan skor dalam persentase adalah 32,08\% dari skor total ideal dihitung dengan persamaan berikut.

$\mathrm{P}=\frac{\bar{X}}{\text { skor ideal }} \times 100 \%=\frac{3,79}{12} \times 100 \%=31,58 \%$

\section{d. Pengujian Hipotesis}

Analisis korelasi yang dilakukan menggunakan analisis korelasi Product Moment yang dikembangkan oleh Person. Korelasi Product Moment dari Pearson digunakan karena data yang didapatkan berupa data interval. Berdasarkan hasil analisis korelasi variabel kemampuan berpikir kreatif dan prestasi belajar sebesar 0,584. Hal ini menunjukkan hubungan yang cukup tinggi antara kemampuan berpikir kreatif dan prestasi belajar. Hasil analisis korelasi variabel kemampuan berpikir kritis dan prestasi belajar sebesar 0,591. Hal ini menunjukkan hubungan yang cukup tinggi antara kemampuan berpikir kritis dan prestasi belajar. Analisis regresi ganda merupakan teknik analisis statistik parametrik yang digunakan untuk menguji variasi variabel kriterium oleh beberapa variabel prediktor. Penelitian ini memiliki variabel prediktor $1\left(\mathrm{X}_{1}\right)$ kemampuan berpikir kreatif, variabel prediktor $2\left(\mathrm{X}_{2}\right)$ kemampuan berpikir kritis, dan variabel kriterium (Y) prestasi belajar. Analisis regresi digunakan untuk menemukan koefisien beta dari hubungan variabel

bebas (prediktor) kemampuan berpikir kreatif $\left(\mathrm{X}_{1}\right)$ dan kritis $\left(\mathrm{X}_{2}\right)$ dengan variabel terikat (kriterium) prestasi belajar (Y) melalui rumus sebagai berikut:

$\mathrm{Y}=\beta_{0}+\beta_{1} \mathrm{X}_{1}+\beta_{2} \mathrm{X}_{2}$ 
Keterangan:

Y = kriterium,

$\beta_{0}=$ bilangan konstanta (beta 0 ),

$\beta_{1}$ = bilangan konstanta $\mathrm{X}_{1}\left(\right.$ beta $\left.\mathrm{X}_{1}\right)$,

$\mathrm{X}_{1}=$ bilangan prediktor 1 ,

$\beta_{2}=$ bilangan konstanta $\mathrm{X}_{2}\left(\right.$ beta $\left.\mathrm{X}_{2}\right)$,

$\mathrm{X}_{2}$ = bilangan prediktor 2 (Draper, 1998).

Analisis regresi dilakukan dengan program komputer SPSS PASW

Statistics 18. Langkah-langkah analisis regresi adalah:

1) Mencari Persamaan Regresi

Berdasarkan hasil analisis dalam Tabel Coefficients (a) didapatkan nilai konstanta $\left(\beta_{0}\right)$ sebesar 1,312; nilai koefisien variabel X1 ( $\left.\beta_{1}\right)$ adalah 0,104; dan konstanta variabel X2 ( $\left.\beta_{2}\right)$ adalah 0,069 . Jadi persamaan regresinya

adalah: $\mathrm{Y}=1,312+0,104 \mathrm{X}_{1}+0,069 \mathrm{X}_{2}$

Konstanta sebesar 1,312 menyatakan bahwa jika tidak terdapat kenaikan skor dari kemampuan berpikir kreatif $\left(\mathrm{X}_{1}\right)$ dan kritis $\left(\mathrm{X}_{2}\right)$, maka skor prestasi belajar adalah sebesar 1,312. Koefisien regresi sebesar 0,104 untuk variabel $\mathrm{X}_{1}$ dan 0,069 untuk variabel $\mathrm{X}_{2}$ menyatakan bahwa setiap penambahan satu skor kemampuan berpikir kreatif dan kritis akan memberikan kenaikan sebesar 0,104 dan 0,069 secara bersama-sama.

2) Menghitung Koefisien Determinasi $\left(\mathrm{R}^{2}\right)$ dengan persamaan:

$R_{2}=\frac{\left(\beta \cdot \sum x y\right)+\left(\beta_{2} \cdot \Sigma x_{2} y\right)}{2}$

Berdasarkan hasil analisis dalam Tabel Model Summary (a) didapatkan nilai koefisien determinasi adalah 0,419. Dalam persen menunjukkan bahwa $41,9 \%$ variasi dalam variabel prestasi belajar dapat dijelaskan oleh variasi dalam variabel kemampuan berpikir kreatif dan kritis.

3) Menghitung residu atau kesalahan ramalan (Res)

Res $=\left(1-\mathrm{R}^{2}\right)\left(\sum \mathrm{y}^{2}\right)$

Berdasarkan hasil analisis dalam Tabel Model Summary (a) diketahui nilai residu atau kesalahan ramalan dari analisis ini adalah 1,651. Santoso (2005:87) menyatakan bahwa semakin kecil kesalahan ramalkan akan menghasilkan model regresi yang semakin tepat dalam memprediksi variabel dependen penelitian.

4) Menghitung taraf korelasi (R)

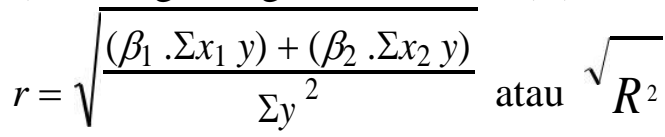

Berdasarkan hasil analisis dalam Tabel Model Summary (a) didapatkan nilai taraf korelasi adalah 0,652. Koefisien ini adalah korelasi ganda antara variabel kemampuan berpikir kreatif dan kritis dengan prestasi belajar. Variabel 
kemampuan berpikir kreatif dan kritis secara bersama-sama sebagai satu tim prediktor berkorelasi dengan prestasi belajar. Korelasi ganda antara kemampuan berpikir kreatif dan kritis dengan prestasi belajar adalah tinggi.

5) Menghitung harga $\mathrm{F}$ regresi

$$
F=\frac{R^{2}(N-m-1)}{m\left(1-R^{2}\right)}
$$

Dengan:

$\mathrm{N}=$ Jumlah sampel

$\mathrm{m}=$ Jumlah prediktor $=2$

Hipotesis penelitian ini adalah:

Ha : Terdapat pengaruh yang signifikan dan simultan antara kemampuan berpikir kreatif dan kritis terhadap prestasi belajar

Ho : Tidak terdapat pengaruh yang signifikan dan simultan antara kemampuan berpikir kreatif dan kritis terhadap prestasi belajar

Berdasarkan hasil analisis dalam Tabel ANOVA (a) didapatkan nilai Fregresi adalah 69,617 dengan signifikansi 0,000(a). Harga Ftabel dengan taraf signifikansi 5\% adalah 3,04. Hasil analisis ini diketahui bahwa harga Fregresi lebih besar daripada $F_{\text {tabel }}$ sebesar 3,04. Hal ini menunjukkan bahwa hipotesis alternatif diterima dan hipotesis nihil ditolak, dengan demikian hipotesis yang menyatakan terdapat hubungan yang simultan antara kemampuan berpikir kreatif dan kritis terhadap prestasi belajar diterima. Riduwan (2007:63) menyatakan bahwa dasar pengambilan keputusan signifikansi hipotesis adalah:

- Jika nilai probabilitas 0,05 lebih kecil atau sama dengan nilai probabilitas Sig atau $[0,05 \leq \mathrm{Sig}]$, maka Ho diterima dan Ha ditolak, artinya tidak signifikan;

- Jika nilai probabilitas 0,05 lebih besar dengan nilai probabilitas Sig atau [0,05

> Sig], maka Ho ditolak dan Ha diterima, artinya signifikan.

Pengujian signifikansinya dengan membandingkan nilai Sig yang menunjukkan signifikansi korelasi antara variabel kemampuan berpikir kreatif dan prestasi belajar. Nilai Sig yang diperoleh sebesar 0,000; sehingga dengan taraf signifikansi 0,05 lebih besar dari nilai Sig atau [0,05 > 0,000], maka Ho ditolak dan Ha diterima. Artinya terdapat hubungan yang signifikan antara kemampuan berpikir kreatif dan prestasi belajar. Pengujian signifikansinya dengan membandingkan nilai Sig yang menunjukkan signifikansi korelasi antara variabel kemampuan berpikir kritis dan prestasi belajar. Nilai Sig yang diperoleh sebesar 0,000; sehingga dengan taraf signifikansi 0,05 lebih besar dari nilai Sig atau [0,05 $>0,000]$, maka Ho ditolak dan Ha diterima. Artinya terdapat hubungan yang signifikan antara kemampuan berpikir kritis dan prestasi belajar. Pada kolom Sig. pada tabel ANOVA terdapat nilai probabilitas signifikansi 0,000 lebih kecil daripada nilai probabilitas 0,05 atau nilai $0,05>0,000$; maka Ho ditolak dan $\mathrm{Ha}$ diterima, dengan kata lain hipotesis yang menyatakan terdapat pengaruh yang signifikan dan simultan antara kemampuan berpikir kreatif dan kritis terhadap prestasi belajar diterima. 


\section{e. Sumbangan Relatif dan Efektif Kemampuan Berpikir Kreatif dan Kritis terhadap Prestasi Belajar}

Langkah-langkah menentukan sumbangan relatif dan efektif kemampuan berpikir kreatif dan kritis terhadap prestasi belajar berikut. Menghitung Sumbangan Efektif (SE) dan Sumbangan Relatif (SR). Sumbangan Relatif dari variabel diukur menggunakan persamaan:

$S R=\frac{\beta\left(\sum_{12} y\right)}{J K_{\text {reg }}} \times 100 \%$

Berdasarkan Tabel Anova(a) besarnya Jumlah Kuadrat Regresi (JKreg) atau Sum of Square adalah 379,619; maka besarnya sumbangan relatif variabel kemampuan berpikir kreatif adalah:

$$
\begin{aligned}
& S R_{x 1}=\frac{\beta\left(\sum x y\right)}{J K_{r e g}^{1}} \times 100 \% \\
& S R_{x 1}=\frac{0,104(1753,42)}{379,619} \times 100 \% \\
& S R_{x 1}=48,04 \%
\end{aligned}
$$

Besarnya sumbangan relatif variabel kemampuan berpikir kritis adalah:

$$
\begin{aligned}
& S R_{x 2}=\frac{\beta\left(\sum x y\right)}{J K_{\text {reg }}} \times 100 \% \\
& S R_{x 2}=\frac{0,069(2827,23)}{379,619} \times 100 \% \\
& S R_{x 1}=51,39 \%
\end{aligned}
$$

Jadi besarnya sumbangan relatif variabel kemampuan berpikir kreatif adalah $48,04 \%$ dan sumbangan relatif variabel kemampuan berpikir kritis adalah $51,39 \%$ terhadap prestasi belajar. Koefisien determinasi dari variabel kemampuan berpikir kreatif dan kritis terhadap variabel prestasi belajar adalah 0,419. Hal ini berarti bahwa $41,9 \%$ variasi dalam variabel prestasi belajar dapat dijelaskan oleh variasi dalam variabel kemampuan berpikir kreatif dan kritis, dengan kata lain koefisien determinasi menunjukkan efektivitas prediksi atau efektivitas garis regresi yang terbentuk dari prediktor X1 dan X2 terhadap kriterium Y. Besarnya sumbangan efektif dari masing-masing prediktor ditentukan dari sumbangan relatifnya. Sehingga sumbangan efektif variabel prediktor kemampuan berpikir kreatif $(X 1)$ terhadap variabel kriterium prestasi belajar adalah:

$$
\begin{aligned}
S E_{x 1} & =\left(S R_{x 1}\right)\left(R^{2}\right) \\
& =48,04 \% \times 0,419 \\
& =20,13 \%
\end{aligned}
$$

Dan sumbangan efektif variabel prediktor kemampuan berpikir kritis (X2) terhadap variabel kriterium prestasi belajar adalah:

$$
\begin{aligned}
S E_{x 2} & =\left(S R_{x 2}\right)\left(R^{2}\right) \\
& =51,39 \% \times \\
& 0,419=21,53 \%
\end{aligned}
$$


Jadi besarnya sumbangan efektif variabel kemampuan berpikir kreatif adalah 20,13\% dan sumbangan efektif variabel kemampuan berpikir kritis adalah $21,53 \%$ terhadap prestasi belajar dan variabel lain yang mempengaruhi prestasi belajar di luar penelitian sebesar 58,34\%. Perhitungan indeks determinasi (sumbangan efektif) variabel penelitian diinterpretasikan pada Gambar 5.

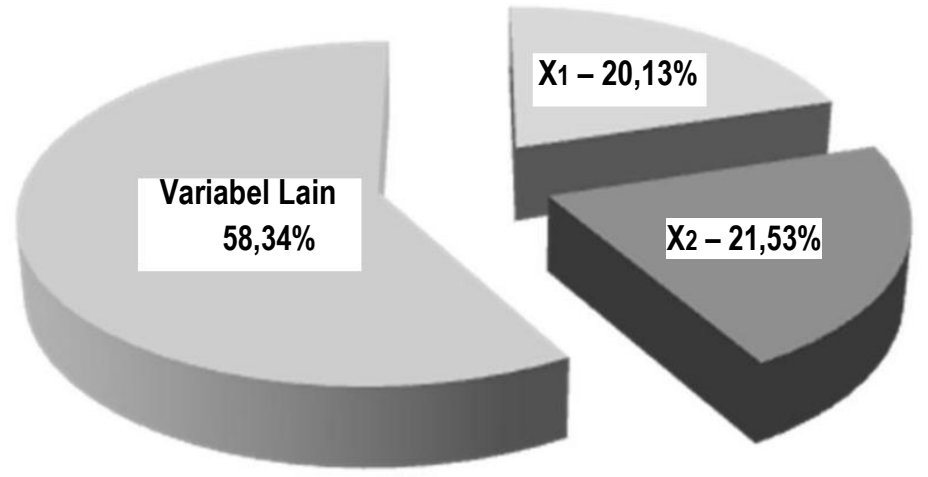

Gambar 5 Diagram Persentase Sumbangan Efektif Variabel Penelitian (X1 dan X2) dan Variabel Lain terhadap Variabel Y

\section{Pembahasan}

\section{Tingkat Kemampuan Berpikir Kreatif}

Berdasarkan hasil analisis data didapatkan mean variabel kemampuan berpikir kreatif adalah 10,94 dengan simpangan baku 7,296. Perolehan skor berpikir kreatif dalam persentase adalah sebesar $39,07 \%$ dari total skor ideal sehingga dapat disimpulkan bahwa tingkat kemampuan berpikir kreatif mahasiswa masih kurang. Hasil penelitian ini mendukung pendapat On (2000) yang menyatakan bahwa pembelajaran Matakuliah Konsep Sains II hanya menekankan proses pemahaman fenomena alam saja yakni proses deduktif, padahal pada kenyataannya Matakuliah Konsep Sains II merupakan ilmu pengetahuan yang dibangun atas dasar fakta, memerlukan verifikasi, dan memiliki keterbatasan validitas.

Lebih lanjut On menyatakan bahwa dalam pembelajaran Matakuliah Konsep Sains II mahasiswa diajarkan terlatih menurunkan rumus, sebaliknya tidak diberi ruang untuk melatih melakukan generalisasi, abstraksi, atau idealisasi dari fakta atau fenomena alam untuk merumuskan suatu model teori. Padahal, dengan melakukan generalisasi inilah tumbuh kreativitas anak dalam melihat fenomena alam. Hasil penelitian ini memberikan bukti hasil studi observasi yang menunjukkan bahwa mahasiswa belum mendapatkan kegiatan pembelajaran Matakuliah Konsep Sains II yang mengintegrasikan kemampuan berpikir kreatif.

\section{Tingkat Kemampuan Berpikir Kritis}

Berdasarkan hasil analisis data didapatkan mean variabel kemampuan berpikir kritis adalah 19,15 dengan simpangan baku 11,611. Perolehan skor berpikir kreatif dalam persentase adalah sebesar $31,92 \%$ dari total skor ideal sehingga dapat disimpulkan bahwa tingkat kemampuan berpikir kritis mahasiswa masih rendah. Persentase ini juga lebih rendah daripada variabel kemampuan berpikir kreatif.

Kesulitan mahasiswa dalam memanfaatkan kemampuan berpikir kritis ini sejalan dengan Rahmawati (2008) yang menyatakan bahwa pendidikan di Indonesia ini belum mengarahkan pada kemampuan mahasiswa untuk berpikir kritis. 
Mahasiswa terbiasa mendengarkan penjelasan dosen di kelas, mencatat, dan membawa pekerjaan rumah setelah pulang dari kuliah. Mahasiswa tidak terbiasa mengemukakan pendapat kritis terhadap suatu permasalahan yang dihadapi. Hal ini akan menyebabkan mahasiswa mengalami kesulitan dalam menghadapi permasalahan setelah mahasiswa keluar dari lingkungan kampus dan terjun ke dalam masyarakat.

\section{Tingkat Prestasi Belajar Matakuliah Konsep Sains II}

Berdasarkan hasil analisis data didapatkan mean variabel prestasi belajar Matakuliah Konsep Sains II adalah 3,79 dengan simpangan baku 2,167. Perolehan skor prestasi belajar Matakuliah Konsep Sains II dalam persentase adalah sebesar $31,58 \%$ dari total skor ideal sehingga dapat disimpulkan bahwa tingkat prestasi belajar mahasiswa Matakuliah Konsep Sains II masih rendah.

Hasil penelitian ini menunjukkan bahwa materi Matakuliah Konsep Sains II belum begitu bermakna bagi mahasiswa. Mahasiswa cenderung melupakan materi-materi sebelumnya yang telah dipelajari dan mengalami kesulitan jika harus mengingat kembali materi Matakuliah Konsep Sains II yang telah lalu. Hasil penelitian ini sesuai dengan hasil studi pendahuluan berupa wawancara kepada sampel penelitian yang menyatakan bahwa ketika berada di dalam kelas pada waktu jam kuliah Matakuliah Konsep Sains II, mahasiswa banyak yang belum mengerti dengan materi dan merasa kesulitan dengan materi yang diberikan. Hal ini berlanjut dengan begitu keluar dari kelas mahasiswa tidak dapat mengingat kembali materi yang baru saja dipelajari. Hasil studi pendahuluan juga menunjukkan bahwa Matakuliah Konsep Sains II merupakan pelajaran yang belum menyenangkan dan sulit, di samping itu, minat mahasiswa pada Matakuliah Konsep Sains II masih rendah.

Mahasiswa dapat meningkat prestasi belajar Matakuliah Konsep Sains II tersebut dengan memperhatikan faktor-faktor tertentu. Mahasiswa dapat memulai dengan menyukai Matakuliah Konsep Sains II dan mencari sisi-sisi menarik dari Matakuliah Konsep Sains II yang selama ini belum disadari oleh mahasiswa. Kemudian dosen dan mahasiswa dapat bekerja sama untuk menciptakan kondisi pembelajaran Matakuliah Konsep Sains II yang aktif, kreatif, efektif, inovatif, dan menyenangkan. Dosen dan mahasiswa dapat mempersiapkan materi-materi pendukung yang bisa mempermudah mempelajari Matakuliah Konsep Sains II, yang pada akhirnya akan tercipta kondisi yang menyenangkan bagi dosen dan mahasiswa dalam melaksanakan kegiatan pembelajaran. Pelaksanaan kegiatan pembelajaran akan menghasilkan perkuliahan yang bermakna dan berkesan bagi mahasiswa, sekaligus dapat membuat mahasiswa selalu teringat dengan suasana pembelajaran, termasuk materi pembelajaran yang telah dipelajari.

\section{Hubungan Kemampuan Berpikir Kreatif dan Kritis dengan Prestasi Belajar Matakuliah Konsep Sains II}

Berdasarkan hasil analisis data dan pengujian hipotesis didapatkan kesimpulan bahwa kemampuan berpikir kreatif dan kritis berpengaruh secara simultan dan signifikan terhadap prestasi belajar Matakuliah Konsep Sains II mahasiswa. Variabel kemampuan berpikir kreatif memiliki koefisien beta 0,104 dalam berhubungan dengan prestasi belajar Matakuliah Konsep Sains II. Penelitian ini mendukung hasil penelitian yang dilakukan oleh Ernawati (2000) yang 
menunjukkan bahwa terdapat hubungan yang positif antara berpikir kreatif dengan prestasi belajar, dengan kemampuan berpikir kreatif memberikan sumbangan efektif sebesar 34,4\% terhadap prestasi belajar. Penelitian yang dilakukan Siregar (2006) yang menghasilkan korelasi positif antara kreativitas dengan prestasi belajar matematika yang ditunjukkan oleh koefisien determinasi $\mathrm{R}=0,143$ atau 14,3\%.

Variabel kemampuan berpikir kritis memiliki koefisien beta 0,069 dalam berhubungan dengan variabel prestasi belajar Matakuliah Konsep Sains II. Penelitian ini mendukung penelitian-penelitian terdahulu antara lain penelitian yang dilakukan oleh Ragasa (2007) yang menunjukkan berpikir kritis mempengaruhi prestasi belajar statistik dasar dengan koefisien regresi sebesar 0,222 . Hasil penelitian juga didukung oleh penelitian Wu (1992) yang meneliti hubungan kemampuan berpikir kritis dengan prestasi belajar siswa sekolah dasar dan menengah dengan penelitian menunjukkan bahwa terdapat hubungan antara kemampuan berpikir kritis dengan prestasi belajar dengan koefisien korelasi sebesar 0,45 untuk siswa sekolah dasar dan 0,43 untuk siswa sekolah menengah.

Hasil pengujian hipotesis dari penelitian ini menunjukkan bahwa kemampuan berpikir kreatif dan kritis berpengaruh secara simultan dan signifikan terhadap prestasi belajar Matakuliah Konsep Sains II mahasiswa. Temuan ini menunjukkan bahwa mengembangkan kemampuan berpikir kreatif dan kritis mahasiswa sangat diperlukan, dan sesuai dengan teori yang dikemukakan oleh Munandar (2002) yang menunjukkan bahwa kemampuan berpikir kreatif diperlukan dalam kegiatan pembelajaran, dan juga sejalan dengan teori yang dikemukakan oleh Marzano (1989) yang menjelaskan bahwa kemampuan berpikir kritis diperlukan dalam kegiatan pembelajaran karena pengembangan kemampuan berpikir kritis dalam kegiatan pembelajaran akan memberikan sumbangsih yang positif terhadap prestasi belajar mahasiswa.

\section{Sumbangan Relatif dan Efektif Kemampuan Berpikir Kreatif dan Kritis terhadap Prestasi Belajar Matakuliah Konsep Sains II}

Variabel kemampuan berpikir kreatif memberikan sumbangan relatif sebesar 48,04\% dan sumbangan efektif sebesar 20,13\% terhadap prestasi belajar Matakuliah Konsep Sains II; sedangkan variabel kemampuan berpikir kritis memberikan sumbangan relatif sebesar 51,39\% dan memberikan sumbangan efektif sebesar 21,53\%; sedangkan sisanya yaitu 58,34\% merupakan variabel lain di luar variabel kemampuan berpikir kreatif dan kemampuan berpikir kritis yang mempengaruhi prestasi belajar Matakuliah Konsep Sains II yang tidak diteliti dalam penelitian ini (Gambar 4.4). Kegiatan pembelajaran yang melibatkan kemampuan berpikir kreatif dan kemampuan berpikir kritis akan dapat meningkatkan prestasi belajar Matakuliah Konsep Sains II. Berdasarkan hasil di atas disimpulkan bahwa kemampuan berpikir kritis memberikan kontribusi lebih besar terhadap variabel prestasi belajar Matakuliah Konsep Sains II daripada variabel kemampuan berpikir kreatif.

Hasil penelitian ini diharapkan dapat memberikan masukan yang positif bagi dosen dalam membimbing Matakuliah Konsep Sains II. Dosen dapat memanfaatkan hasil penelitian ini untuk mengembangkan kegiatan pembelajaran Matakuliah Konsep Sains II dalam upaya mengembangkan potensi kemampuan berpikir kreatif dan kritis yang dimiliki mahasiswa, dan menjadikan mahasiswa mampu meningkatkan prestasi belajarnya dengan sangat memuaskan. 


\section{Simpulan dan Saran}

Bertolak dari hasil penelitian dan pembahasan, dapat dikemukakan kesimpulan, yakni: (1) tingkat kemampuan berpikir kreatif mahasiswa Matakuliah Konsep Sains II termasuk dalam kategori rendah; (2) tingkat kemampuan berpikir kritis mahasiswa Matakuliah Konsep Sains II termasuk dalam kategori rendah; (3) tingkat prestasi belajar mahasiswa Matakuliah Konsep Sains II termasuk dalam kategori rendah; dan (4) terdapat pengaruh yang signifikan pada variabel kemampuan berpikir kreatif dan kritis terhadap prestasi belajar mahasiswa Matakuliah Konsep Sains II Program Studi PGSD IKIP PGRI MADIUN.

Berdasarkan kesimpulan, saran yang disampaikan adalah bagi dosen dapat memanfaatkan hasil penelitian ini sebagai bahan kajian dan masukan dalam memperbaiki perkuliahan, khususnya perkuliahan Matakuliah Konsep Sains II agar menghasilkan calon guru yang profesional. Karena kemampuan berpikir kreatif dan kritis mahasiswa masih rendah dan terbukti bahwa kemampuan berpikir kreatif dan kritis berpengaruh secara signifikan terhadap prestasi belajar, disarankan kepada dosen untuk menggunakan model-model perkuliahan yang membangkitkan atau mendorong mahasiswa untuk berpikir kreatif dan kritis secara terintegrasi. Beberapa model pembelajaran yang dapat mengembangkan kemampuan berpikir kreatif dan kritis sekaligus meningkatkan prestasi belajar antara lain Contextual Teaching and Learning (CTL), Inquiry, Problem Based Instruction (PBI), dan model pembelajaran yang menekankan pada kerjasama kelompok. Selain itu dosen hendaknya memperkaya dan meningkatkan kemampuan dalam menggunakan model-model pembelajaran tersebut agar pembelajaran yang dilaksanakannya berhasil dengan baik dan bermakna bagi mahasiswa.

Bagi Ketua Program Studi hendaknya memperhatikan kebutuhan mahasiswa dalam mengembangkan kemampuan lain yang bermanfaat bagi masa depan mahasiswa. Mengadakan workshop pembelajaran bagi dosen-dosen sebagai upaya meningkatkan kualias perkuliahan. Perkuliahan yang berkualitas dapat mendorong mahasiswa (calon guru) yang berdaya saing dan berpikir logis. Bagi Dekan hendaknya melakukan pembenahan untuk terus meningkatkan kualitas perkuliahan. Patut mencanangkan program guna mewadahi mahasiswa untuk meningkatkan kemampuan berpikir kreatif dan kritis mahasiswa. Memberikan keluasan kepada para dosen untuk mengembangkan potensi diri dalam upaya meningkatkan mutu perkuliahan. Bagi peneliti selanjutnya patut melakukan verifikasi hasil riset ini. Peneliti selanjutnya dapat mengembangkan penelitian tentang kegiatan pembelajaran yang dapat mendorong dan meningkatkan kemampuan berpikir kreatif dan kritis sekaligus meningkatkan prestasi belajar mahasiswa dengan metodologi dan ruang lingkup yang berbeda seperti penelitian eksperimen, Research and Development, ataupun Penelitian Tindakan Kelas (Action Research) 


\section{DAFTAR RUJUKAN}

ADVY. 2007. Kreativitas, (online), (http://www.advy.ac.id, diakses 4 April 2007).

Arikunto, S. 2002. Dasar-dasar Evaluasi Pendidikan (Edisi Revisi). Jakarta: Bumi Aksara.

Arum, N. W. 2000. Pengembangan Pembelajaran dengan Pola Pendekatan Sikap Berpikir Kritis dan Kreatif (SPIKK) untuk Meningkatkan Pemahaman Konsep Fisika SMPN 17 Malang. Tesis tidak diterbitkan. Malang: Program Pascasarjana Universitas Negeri Malang.

Azwar, S. 2007. Tes Prestasi Fungsi dan Pengembangan Pengukuran Prestasi Belajar. Yogyakarta: Pustaka Belajar.

Bachman, E. 2005. Metode Belajar Berpikir Kritis dan Inovatif. Terjemahan oleh Bahrul Ulum. 2005. Jakarta: Prestasi Pustaka.

Devi, P. K. 2008. Higher Order Thinking (HOT) Diklat Guru SMA Daerah Alumnus, (online), (http//www.curriki.org, diakses 19 Oktober 2008).

Draper, N. R., dan Smith, H. 1998. Applied Regression Analysis. New York: John Wiley and Sons.

Ennis, R. H. 2006. An Annotated List of Critical Thinking Tests, (online), (http://faculty.ed.uiuc.edu/rhennis/testlistrevised606.htm,_diakses 31 Desember 2007).

Furchan, A. 1982. Pengantar Penelitian dalam Pendidikan. Surabaya: Usaha Nasional.

Gunawan, I. 2013. Statistika untuk Kependidikan Sekolah Dasar. Yogyakarta: Penerbit Ombak.

Hadi, S. 1990. Analisis Regresi. Yogyakarta: Andi Offset.

Harris, R. 1998. Introduction to Creative Thinking, (online), (http://www.virtualsalt.com, diakses 5 Agustus 2007)

Hassoubah, Z. I. 2007. Mengasah Pikiran Kreatif dan Kritis: Disertai Ilustrasi dan Latihan. Bandung: Nuansa.

Jargodzki, C. P., dan Potter, F. Mania Fisika. Bandung: Pakaraya.

Johnson, L. dan Lamb, A. 2000. Critical and Creative Thinking - Bloom's Taxonomy, (online), (http://eduscape.com, diakses 5 Agustus 2007)

Krathwohl, D. R. dan Anderson, L. W.2001. A Taxonomy for Learning, Teaching, and Assessing. New York: Addison Wesley Longman, Inc.

Marzano, R. J. et. al. 1989. Dimensions of Thinking: A Framework for Curriculum and Instruction. Virginia: ASCD.

Mulyasa, E. 2005. Implementasi Kurikulum 2004: Panduan Pembelajaran KBK. Bandung: PT Remaja Rosdakarya. 
Munandar, S. C. U. 1990. Mengembangkan Bakat dan Kreativitas Anak Sekolah: Petunjuk bagi Para Guru dan Orang Tua. Jakarta: PT Gramedia Pustaka Utama.

Munandar, S. C. U. 2002. Kreativitas dan Keberbakatan Strategi Mewujudkan Potensi Kreatif dan bakat. Jakarta: PT Gramedia Pustaka utama.

Nurcahyo, P. I. 2005. Berpikir Kritis, (online), (http://priyadi.net/archives /2005/04/21/berpikir-kritis/, diakses 9 juli 2008).

On, T. M. Pengajaran Fisika Membunuh Kreativitas, (online), (www.duniaguru.com, diakses 12 Februari 2007).

Ragasa, C. Y. 2007. A Correlation of Critical Thinking with Achievement in Statistics and Attitude toward Statistics, (online), (http://www.icme11.org/node/1375, diakses 29 Oktober 2008).

Rahmawati, Y. 2008. Susahnya Berpikir Kritis: Sebuah Refleksi Diri, (online), (http://pendidikansains.wordpress.com/2008/04/17/susahnya-berpikirkritis-sebuah-refleksi-diri/, diakses 7 September 2008).

Riduwan, dan Kuncoro, E. A. 2007. Cara Menggunakan dan Memaknai Analisis Jalur (Path Analysis). Bandung: Alfabeta.

Ruslan, R. 2004. Metode Penelitian Public Relations dan Komunikasi. Jakarta: Raja Grafindo Persada.

Setiono, A. 2007. Berpikir Kreatif, (online), (http://agustinussetiono. wordpress.com, diakses 13 Oktober 2008).

Setyadin, B. (bsyadin@yahoo.com). 30 Mei 2007. Analisis Jalur. e-mail kepada Imam Gunawan (imamgun @ rocketmail.com).

Setyadin, B. 2005. Desain dan Metode Penelitian Kuantitatif. Modul IV disajikan dalam Penataran Tenaga Fungsional Akademik Politeknik Kotabaru, Lembaga Penelitian Universitas Negeri Malang, Kotabaru Kalimantan Selatan, 15 - 22 Februari 2005.

Siregar, J. 2006. Kontribusi Sikap terhadap Matematika Berpikir Kreatif dan Aktivitas Siswa terhadap Prestasi Belajar Matematika Kelas I SMA Negeri I Pringsewu Kabupaten Tanggamus, (online), (http://digilib.unila.ac.id, diakses 14 October 2008).

Sudaryanto. 2007. Pembelajaran Kemampuan Berpikir Kritis, (online), (http://www.fk.undip.ac.id, diakses 9 Juli 2008).

Sugiyono. 2005. Metode Penelitian Administrasi. Bandung: Alfabeta.

Sugiyono. 2007. Statistika untuk Penelitian. Bandung: Alfabeta.

Sungkowo. 2003. Statistik Dasar. Malang: Universitas Negeri Malang.

Suparmoko. 1988. Metode Kuantitatif dalam Penelitian Ilmu Sosial dan Pendidikan. Bandung: Remaja Rosdakarya.

Surakhmad, W. 1982. Pengantar Penelitian Ilmiah: Dasar-Dasar Metode dan Teknik. Bandung: Tarsito. 
40 | Premiere Educandum, Volume 4 Nomor 1, Juni 2014, 10-40

Suryabrata, S. 2005. Psikologi Pendidikan. Jakarta: PT Raja Grafindo Persada.

Wardani, L. K. 2003. Berpikir Kritis Kreatif (Sebuah Model Pendidikan di Bidang Desain Interior), (online), (http//digilip.petra.ac.id, diakses 20 Oktober 2008).

Winarsunu, T. 2002. Statistik dalam Penelitian Psikologi dan Pendidikan. Malang: Universitas Muhammadiyah Malang.

Wiyono, B. B. 2004. Metode Penelitian Kuantitatif. Malang: Program SP4 Jurusan Administrasi Pendidikan Fakultas Ilmu Pendidikan Universitas Negeri Malang.

Wu, J. J., dan Yeh, Y. C. 1992. The Relationship Between Critical Thinking and Academic Achievement Among Elementary and Secondary School Students, (online), (http://www.fed.cuhk.edu.hk, diakses 29 Oktober 2008). 